\title{
New data from the Middle Jurassic of China shed light on the phylogeny and origin of the proboscis in the Mesopsychidae (Insecta: Mecoptera)
}

Xiaodan Lin', Matthew J. H. Shih², Conrad C. Labandeira ${ }^{1,3,4}$ and Dong Ren ${ }^{1 *}$

\begin{abstract}
Background: The Mesopsychidae is an extinct family of Mecoptera, comprising eleven described genera from Upper Permian to Lower Cretaceous deposits. In 2009, several well-preserved mesopsychids with long proboscides were reported from the mid Mesozoic of Northeastern China, suggesting the presence of pollination mutualisms with gymnosperm plants and highlighting their elevated genus-level diversity. Since that time, additional mesopsychid taxa have been described. However, the phylogeny of genera within Mesopsychidae has not been studied formally, attributable to the limited number of well-preserved fossils.

Results: Here, we describe two new species, Lichnomesopsyche prochorista sp. nov. and Vitimopsyche pristina sp. nov. and revise the diagnosis of Lichnomesopsyche daohugouensis Ren, Labandeira and Shih, 2010, based on ten specimens from the latest Middle Jurassic Jiulongshan Formation of Inner Mongolia, China. After compiling data from these new fossil species and previously reported representative taxa, we conducted phylogenetic analyses and geometric morphometric studies that now shed light on the taxonomy and phylogeny of Mesopsychidae. We also evaluate the recurring origin of the siphonate proboscis in the Mecoptera and propose an evolutionary developmental model for its multiple origins.

Conclusions: Phylogenetic and geometric morphometric results confirm the establishment of two new species, each to Lichnomesopsyche and Vitimopsyche. Vitimopsyche pristina sp. nov. extends the existence of the genus Vitimopsyche Novokshonov and Sukacheva, 2001, from the mid Lower Cretaceous to the latest Middle Jurassic. Two methods of analyses indicate an affiliation of Mesopsyche dobrokhotovae Novokshonov, 1997 with Permopsyche Bashkuev, 2011. A phylogenetic analysis of the Mesopsychidae supports: 1), Mesopsychidae as a monophyletic group; 2), Mesopsyche as a paraphyletic group, to be revised pending future examination of additional material; and 3), the independent origin of the proboscis in the Pseudopolycentropodidae, its subsequent loss in earliest Mesopsychidae such as Epicharmesopsyche, its re-origination in the common ancestor (or perhaps independently) in the Vitimopsyche and Lichnomesopsyche clades of the Mesopsychidae. The third conclusion indicates that the proboscis originated four or five times within early Mecoptera, whose origin is explained by an evolutionary developmental model.
\end{abstract}

Keywords: Evolutionary developmental model, Fossil insects, Inner Mongolia, Mesozoic, Morphological characteristics, Scorpionfly

\footnotetext{
* Correspondence: rendong@mail.cnu.edu.cn

${ }^{1}$ College of Life Sciences, Capital Normal University, Beijing, China

Full list of author information is available at the end of the article
} 


\section{Background}

One of the iconic narratives in evolutionary biology is that associations between insects such as beetles, moths, flies and bees and flowering plants have resulted in an intricate nexus of coevolution between diversifying angiosperms and their insect pollinator clades from the mid Cretaceous to the present [1, 2]. In 2009, Ren et al. reported eleven species in Mesopsychidae, Aneuretopsychidae and Pseudopolycentropodidae with siphonate proboscides. The authors suggested that these mecopteran siphonate proboscides were used to feed on liquid pollination drops of gymnospermous reproductive structures and likely engaged in pollination mutualisms with gymnosperms during the mid-Mesozoic, long before the similar and independent establishment of coevolutionary associations between nectar-feeding bees, flies, moths, and beetles on angiosperms [3]. Recently, Peñalver et al. described two zhangsolvid flies from Late Cretaceous amber in Spain at $105 \mathrm{Ma}$ (mega-annum) and Myanmar at $100 \mathrm{Ma}$ that possess long proboscides. The Spanish specimen retained gymnosperm pollen adhering to the surface of its abdomen, thus providing evidence that these insects were engaged in pollination mutualisms with gymnosperms [4].

Mecoptera is a small order of insects comprising nine extant families [5] that contrasts with their greater diversity during the Mesozoic, encompassing about 39 extinct families and 207 genera described to date [6]. Within Mecoptera, Mesopsychidae Tillyard, 1917, are a small extinct family, and together with three other families, Aneuretopsychidae [7], Pseudopolycentropodidae [8], and Nedubroviidae [9], form a major clade of basal Mecoptera, the Aneuretopsychina [10], which have elongate, siphonate proboscides, feeding on pollination drops of gymnosperms [3, 11, 12]. Phylogenetic relationships among Mesopsychidae and other mecopteran-related families, including extinct basal panorpoids, extinct basal mecopterans and extant mecopterans previously have been reported $[3,13]$. Currently, eleven genera with 27 species from the Upper Permian to the mid Lower Cretaceous have been assigned to Mesopsychidae [3, 14-24], which are summarized in Table 1. Fossil mesopsychids are known from Australia, Kyrgyzstan, South Africa, Ukraine, Tajikistan, Russia and China.

Recently, we collected ten new specimens of mesopsychids from the latest Middle Jurassic Jiulongshan Formation at Daohugou Village, Shantou Township, from Ningcheng County of Inner Mongolia in Northeastern China. Based on these occurrences, two new species Lichnomesopsyche prochorista sp. nov. and Vitimopsyche pristina sp. nov. - are described. In addition, the diagnosis of Lichnomesopsyche daohugouensis Ren, Labandeira and Shih, 2010, is revised based on five, well-preserved, new specimens of $L$. daohugouensis that display additional species-diagnostic characters of the hind wings which were lacking in the holotype [21].

Vitimopsyche torta was reported by Novokshonov in 2001 from the Lower Cretaceous Zaza Formation at Baissa, in Transbaikalian Russia [19]. Currently, two species, $V$. torta and $V$. kozlovi, have been assigned to Vitimopsyche, and both were described from the Lower Cretaceous. In this report, we describe a new species of Vitimopsyche from latest Middle Jurassic strata. This new find suggests that this genus has existed at least from the latest Middle Jurassic to the mid Lower Cretaceous and has had minimal morphological change for 40 million years [25-27].

Based on data from previously described, representative species and two new species erected herein, a suite of unique characters were chosen for phylogenetic analyses to shed light on the taxonomy, classification and phylogeny of the genera within Mesopsychidae. In addition, geometric morphometric analyses [28-31] for specimens with well-preserved forewings were conducted to supplement the phylogenetic analyses. Geometric morphometric analyses have been used in the study of phenetic relationships (without consideration of evolutionary relationships) among extant and fossil insects and their associations with cycadophyte, ginkgophyte and other land plants $[28,31-35]$. The results from these two methods provide a preliminary understanding of the phylogenetic and phenetic relationships of selected genera of Mesopsychidae.

\section{Methods}

\section{Examined taxa and terminology}

The specimens described herein are housed in the fossil insect collection of the Key Laboratory of Insect Evolution and Environmental Changes, College of Life Sciences, Capital Normal University, Beijing, China (CNUB; Dong Ren, Curator). The specimens were examined using a Leica MZ 16.5 dissecting microscope connected to a Leica DFC500 digital camera, and illustrated with the aid of a drawing tube attached to the microscope. Photographs of entire specimens were taken with a Nikon D7000 digital camera coupled to a Nikkor $65 \mathrm{~mm}$ macro lens. The overlay drawings were prepared by using Adobe Illustrator CS6 and Adobe Photoshop CS5 graphics software. The wing venational nomenclature is based on Novokshonov (1997, 2002) [18, 36].

\section{Measurements and corresponding abbreviations}

Body lengths were measured from the apex of the head, excluding antennae and proboscis, to the apex of the abdomen, excluding appendages. The wing lengths were measured from the base to the apex of wings. The lengths of the antennae were measured from their base to apex. 
Table 1 Summary of all described genera and species of Mesopsychidae

\begin{tabular}{|c|c|c|c|c|}
\hline Genus & Species & Geological age and locality & Preservation status & Reference \\
\hline \multirow[t]{4}{*}{ Permopsyche } & P. issadensis & Upper Permian, Vologda Province, Russia. & Fore- and hind wings. & Bashkuev, 2011 [22] \\
\hline & P. rasnitsyni & Upper Permian, Vologda Province, Russia. & Fore- and hind wings. & Bashkuev, 2011 [22] \\
\hline & P. robustus & Upper Permian, Queensland, Australia. & Incomplete forewing only. & Riek, 1953 [16] \\
\hline & P. belmontensis & Upper Permian, Queensland, Australia. & Fore- and hind wings. & Riek, 1953 [16] \\
\hline \multirow[t]{10}{*}{ Mesopsyche } & M. incompleta & $\begin{array}{l}\text { Uppermost Permian, Vologda Province, } \\
\text { European Russia. }\end{array}$ & Incomplete fore- and hind wings. & Bashkuev, 2011 [22] \\
\hline & M. javorskii & $\begin{array}{l}\text { Uppermost Permian or Lower Triassic, } \\
\text { Vladimir Province, Russia. }\end{array}$ & Hind wing only. & Zalessky, 1935 [54] \\
\hline & M. tongchuanensis & Middle Triassic, Shaanxi Province, China. & Forewing only. & Hong, 2007 [20] \\
\hline & M. shcherbakovi & $\begin{array}{l}\text { Middle-Upper Triassic, Osh Region, } \\
\text { Kyrgyzstan. }\end{array}$ & Fore- and hind wings. & Novokshonov, 1997 [18] \\
\hline & M. ordinate & $\begin{array}{l}\text { Middle-Upper Triassic, Osh Region, } \\
\text { Kyrgyzstan. }\end{array}$ & Fore- and hind wings. & $\begin{array}{l}\text { Novokshonov and Sukatsheva, } \\
2001 \text { [19] }\end{array}$ \\
\hline & M. justa & $\begin{array}{l}\text { Middle-Upper Triassic, Osh Region, } \\
\text { Kyrgyzstan. }\end{array}$ & Fore- and hind wings. & $\begin{array}{l}\text { Novokshonov and Sukatsheva, } \\
2001 \text { [19] }\end{array}$ \\
\hline & M. tortiva & $\begin{array}{l}\text { Middle-Upper Triassic, Osh Region, } \\
\text { Kyrgyzstan. }\end{array}$ & Fore- and hind wings. & $\begin{array}{l}\text { Novokshonov and Sukatsheva, } \\
2001 \text { [19] }\end{array}$ \\
\hline & M. gentica & $\begin{array}{l}\text { Middle-Upper Triassic, Osh Region, } \\
\text { Kyrgyzstan. }\end{array}$ & Fore- and hind wings. & $\begin{array}{l}\text { Novokshonov and Sukatsheva, } \\
2001 \text { [19] }\end{array}$ \\
\hline & M. triareolata & Upper Triassic, Queensland, Australia. & Fore- and hind wings. & Tillyard, 1917 [14] \\
\hline & M. dobrokhotovae & Upper Triassic, Khar'kov Region, Ukraine. & Fore- and hind wings. & Novokshonov, 1997 [18] \\
\hline Mesopanorpodes & M. wianamattensis & $\begin{array}{l}\text { Middle Triassic, New South Wales, } \\
\text { Australia. }\end{array}$ & Incomplete forewing only. & Tillyard, 1918 [15] \\
\hline \multirow[t]{3}{*}{ Mesoses } & M. optata & Upper Triassic, Bird's River, South Africa. & Incomplete forewing only. & Riek, 1976 [17] \\
\hline & M. magna & Upper Triassic, Bird's River, South Africa. & Incomplete forewing only. & Riek, 1976 [17] \\
\hline & M. gayndah & Early Middle Triassic, Gayndah, Australia. & Incomplete forewing only. & Lambkin, 2014 [24] \\
\hline Ptychopteropsis & P. mirabilis & Lower Jurassic, Shurab, Tajikistan. & Forewing only. & Martynov, 1937 [55] \\
\hline Turanopsyche & T. venosa & Lower Jurassic, Shurab, Tajikistan. & Hind wing only. & Martynov, 1937 [55] \\
\hline Ferghanopsyche & F. rotundata & Lower Jurassic, Shurab, Tajikistan. & Forewing only. & Martynov, 1937 [55] \\
\hline \multirow[t]{2}{*}{ Lichnomesopsyche } & L. gloriae, & Middle Jurassic, Inner Mongolia, China. & Complete body with wings. & $\begin{array}{l}\text { Ren, Labandeira and Shih, } \\
2010[21]\end{array}$ \\
\hline & L. daohugouensis & Middle Jurassic, Inner Mongolia, China. & Complete body with wings. & $\begin{array}{l}\text { Ren, Labandeira and Shih, } \\
2010[21]\end{array}$ \\
\hline Epicharmesopsyche & E. pentavenulosa & Middle Jurassic, Inner Mongolia, China. & Complete body with wings. & $\begin{array}{l}\text { Shih, Qiao, Labandeira and } \\
\text { Ren, } 2013 \text { [23] }\end{array}$ \\
\hline \multirow[t]{2}{*}{ Vitimopsyche } & V. torta & Lower Cretaceous, Transbaikalia, Russia. & Forewing only. & $\begin{array}{l}\text { Novokshonov and Sukacheva, } \\
2001 \text { [19] }\end{array}$ \\
\hline & V. kozlovi & Lower Cretaceous, Hebei, China. & Complete body with wings. & $\begin{array}{l}\text { Ren, Labandeira and Shih, } \\
2010 \text { [21] }\end{array}$ \\
\hline Baissopsyche & B. pura & Lower Cretaceous, Transbaikalia, Russia. & Fore- and hindwings. & $\begin{array}{l}\text { Novokshonov and Sukacheva, } \\
2001 \text { 19] }\end{array}$ \\
\hline
\end{tabular}

Corresponding text and figure abbreviations are: Sc, subcosta; R1, first branch of the radius; Rs, radial sector; MA, anterior media; MP, posterior media; $\mathrm{CuA}$, anterior cubitus; CuP, posterior cubitus; $1 \mathrm{~A}$, first branch of the anal vein; $2 \mathrm{~A}$, second branch of the anal vein.

\section{Phylogenetic analysis}

We conducted phylogenetic analyses to elucidate the taxonomic and phylogenetic positions of the two new species and clarify the genus-level relationships of Mesopsychidae. Because many reported fossils lack wellpreserved features of the body, only two body characters (characters 24 and 25) were used in this study (Table 2). The other 24 are wing characters; characters 0-22 are forewing characters (Table 2, Additional file 1: Figure S1), and character 23 is a hind wing character. The character selection partly is attributable to the characters used by Ren et al., 2009 [3] in their phylogenetic analysis 
Table 2 Definition of characters and their states

\begin{tabular}{|c|c|}
\hline No. & Characters and their states \\
\hline 0 & $\begin{array}{l}\text { The relative level between } \mathrm{Sc} \text { ending }\left(\mathrm{SC}_{2}\right) \text { at } \mathrm{C} \text { and } \mathrm{CuA} \text { ending at posterior margin in the forewing: } 0-\mathrm{Sc} \text { ending far proximal to } \\
\mathrm{CuA} \text { ending; } 1 \text { - Sc ending at the same level with or slightly distal or proximal to CuA ending; } 2-\mathrm{Sc} \text { ending far distal from CuA ending. }\end{array}$ \\
\hline 1 & $\begin{array}{l}\text { The relative level of } \mathrm{Sc} \text { fore-branch }\left(\mathrm{SC}_{1}\right) \text { ending point vs. } 1 \mathrm{~A} \text { ending point in the forewing: } 0-\mathrm{SC}_{1} \text { ending point distal to } 1 \mathrm{~A} \text { ending point; } \\
1-\mathrm{SC}_{1} \text { terminus point very close or at the same level with } 1 \mathrm{~A} \text { ending point; } 2-\mathrm{SC}_{1} \text { ending point proximal to } 1 \mathrm{~A} \text { terminus. }\end{array}$ \\
\hline 2 & $\begin{array}{l}\text { Presence of } \mathrm{Sc}_{1} \text {, branches of } \mathrm{Sc}_{2} \text { and crossvein sc-r in forewing: } 0 \text { - with one } \mathrm{Sc}_{2} \text { branch and one } \mathrm{sc}^{-} \mathrm{r}_{;} 1 \text { - with two } \mathrm{Sc}_{2} \text { branches and one } \\
\mathrm{sc}-\mathrm{r} ; 2 \text { - no fore-branch }\left(\mathrm{Sc}_{1}\right) \text { and/or no sc-r. }\end{array}$ \\
\hline 3 & $\begin{array}{l}\text { The relative level between the point of MP origination from CuA and the point of RS + MA forking from R1 in the forewing: } 0-R S+M A \\
\text { forking from R1 slightly distal to MP forking from CuA; } 1 \text { - RS + MA forking from R1 far distal to MP forking from CuA. }\end{array}$ \\
\hline 4 & $\begin{array}{l}\text { The relative level between RS and MA forking points in the forewing: } 0 \text { - MA forking proximal to the RS forking; } 1-\text { RS and MA forking } \\
\text { points very close or at the same level; } 2 \text { - MA forking distal to the RS forking. }\end{array}$ \\
\hline 5 & $\begin{array}{l}\text { The relative level between MA and MP1 }+2 \text { forking points in the forewing: } 0-M P 1+2 \text { (or MP1 }+2+3+4 \text { in outgroup } 1 \text { and outgroup } 2 \text { ) } \\
\text { forking distal to the MA forking; } 1-M P 1+2 \text { forking very close to the MA forking; } 2-M P 1+2 \text { forking proximal to the MA forking. }\end{array}$ \\
\hline 6 & Number of crossveins between R1 and C: $0-$ no crossveins; $1-1$ crossvein; $2-2$ crossveins. \\
\hline 7 & Presence of the crossvein $\mathrm{r} 1$-rs in the forewing: 0 - present; 1 - absent. \\
\hline 8 & Number of RS branches in the forewing: 0 - 3 branches; $1-2$ branches. \\
\hline 9 & Number of MP branches in the forewing: $0->5$ branches; $1-5$ branches; $2-4$ branches. \\
\hline 10 & $\begin{array}{l}\text { The relative level of MP forking point and RS + MA forking point in the forewing: } 0-M P \text { forking proximal to the RS + MA forking; } 1-\text { MP } \\
\text { forking and RS + MA forking are very close or at the same level; } 2-M P \text { forking distal to the RS + MA forking. }\end{array}$ \\
\hline 11 & Posterior margin of forewings emarginated at the CuP vein apex: 0 -absent; 1 - present. \\
\hline 12 & $\begin{array}{l}\text { e inclination of the cup-cua (or cup-mp or CuA base) in the forewing: } 0 \text { - forming }<90^{\circ} \text { angle with CuA; } 1-90^{\circ} \text { or almost } 90^{\circ} \text { angle with } \\
\text { AA; } 2 \text { - forming }>90^{\circ} \text { angle with CuA. }\end{array}$ \\
\hline
\end{tabular}

13 The relative level of cup-cua (or cup-mp or CuA base) vs. MP origination from CuA in the forewing: 0 - cup-cua far distal to MP origination from CuA; 1 - cup-cua very close or slightly distal to MP origination from CuA; 2 - cup-cua proximal to MP origination from CuA.

14 The relative level of CuP and mid-length of the wing in the forewing: 0 - CuP proximal to mid-length of the wing; 1 - CuP almost at the same level or distal to mid-length of the wing.

15 The relative level of $2 \mathrm{~A}$ ending vs. MP origination from CuA in the forewing: $0-2 \mathrm{~A}$ proximal to MP origination from CuA; $1-2 \mathrm{~A}$ almost at the same level or distal to MP origination from CuA.

16 Symmetric spots on both wings: 0 - absent; 1 - present.

17 The relative level of crossvein rs2-ma (rs2-ma1 or rs-ma1) vs. MA1 + 2 forking point in the forewing: 0 - crossvein rs2-ma1 (rs-ma1) distal to $M A 1+2$ forking point; 1 - crossvein rs2-ma proximal to MA1 + 2 forking point.

18 The relative level of crossvein rs2-ma (rs2-ma1 or rs-ma1 or rs3-ma1 for outgroup 2) vs. RS1 2 forking point in the forewing: 0 - crossvein rs2-ma (rs2-ma1 or rs3-ma1 for outgroup 2) distal to RS1 + 2 (RS1 + 2 + 3 for outgroup 2) forking point; 1 - crossvein rs-ma1 proximal to RS1 + 2 forking point.

19 The relative level of crossvein ma-mp1 +2 vs. MA $1+2$ forking point in the forewing: $0-$ crossvein ma-mp $1+2$ slightly distal to MA $1+2$ forking point; 1 - crossvein ma-mp1 + 2 slightly proximal to MA1 +2 forking point; 2 - crossvein ma-mp1 +2 far proximal to MA1 + 2 forking point.

20 The relative level of crossvein mp2-mp3 (mp1 $+2-m p 3$ or mp2 $+3-m p 4)$ vs. MP1 +2 (or MP $1+2+3)$ forking point in the forewing: 0 - crossvein $\mathrm{mp} 1+2$-mp3 proximal to MP1 +2 forking point; 1 - crossvein mp2-mp3 slightly distal to MP1 +2 forking point; 2 - crossvein mp2-mp3 much distal to MP1 +2 forking point.

21 Number of crossveins (excluding sc-c, a1-a2 and a2-a3) in the forewing: $0->10$ crossveins; $1-8-10$ crossveins; $2-<8$ crossveins.

22 The anal area in the forewing: 0 -narrow; 1 - medium; 2 - expanded.

23 Length of Sc in the hind wing: 0 - short (proximal to MA bifurcation); 1 - medium (slightly proximal to MA bifurcation); 2 - long (distal to MA bifurcation).

24 Antennae: 0 - filiform and long antennae; 1 - short and filiform-like antennae; 2 - pectinate (comb-like) antennae.

25 Mouthparts: 0 - siphonate mouthparts not present; 1 - siphonate mouthparts present.

of the Aneuretopsychina, or those scorpionflies characterized by siphonate, proboscate mouthparts. Thirteen mesopsychid species representing five genera with almost completely preserved forewing characters were selected as ingroups for the analysis (Tables 3 and 4). Described species with missing or poorly-preserved characters or possessing unusually inconsistent characters were excluded but summarized in Tables 3 and 4, with reasons for exclusion. Mesopsyche is represented by M. triareolata, M. shcherbakovi and $M$. dobrokhotae, but seven other species were excluded. Mesopanorpodes wianamattensis Tillyard, 1918 and Baissopsyche pura 
Table 3 Summary of the species included in the analyses

\begin{tabular}{|c|c|c|c|c|}
\hline \multirow[t]{2}{*}{ Included species } & \multirow{2}{*}{$\begin{array}{l}\text { Phylogenetic analyses, } \\
\text { Most parsimonious, tree, } \\
\text { and Strict consensus tree }\end{array}$} & \multicolumn{2}{|c|}{ Geometric morphometric analyses } & \multirow[t]{2}{*}{ Comments } \\
\hline & & $\begin{array}{l}38 \text { landmarks, w/o } \\
\text { crossveins, Tree } 1\end{array}$ & $\begin{array}{l}42 \text { landmarks, with } \\
\text { two crossveins, Tree } 2\end{array}$ & \\
\hline Permopsyche rasnitsyni & Yes & Yes & Yes & \\
\hline Permopsyche issadensis & Yes & Yes & Yes & \\
\hline Permopsyche belmontensis & Yes & Yes & Yes & \\
\hline Mesopsyche triareolata & Yes & Yes & Yes & \\
\hline Mesopsyche dobrokhotovae & Yes & Yes & Yes & \\
\hline Mesopsyche shcherbakovi & Yes & Yes & Yes & \\
\hline Lichnomesopsyche gloriae & Yes & Yes & Yes & \\
\hline Lichnomesopsyche daohugouensis & Yes & Yes & Yes & \\
\hline Lichnomesopsyche prochorista & Yes & Yes & Yes & \\
\hline Epicharmesopsyche pentavenulosa & Yes & Yes & No & Most crossveins absent \\
\hline Vitimopsyche torta & Yes & Yes & Yes & \\
\hline Vitimopsyche kozlovi & Yes & Yes & Yes & \\
\hline Vitimopsyche pristina & Yes & Yes & Yes & \\
\hline Permopanorpa inaequalis & Yes & Yes & Yes & Outgroup 1 \\
\hline Protopanorpa longicubitalis & Yes & Yes & Yes & Outgroup 2 \\
\hline Pseudopolycentropus janeannae & Yes & Yes & Yes & Outgroup 3 \\
\hline
\end{tabular}

The age and locality of three outgroups: (1) Permopanorpa inaequalis: Lower Permian, Noble County, Oklahoma, USA, Wellington Formation; (2) Protopanorpa longicubitalis: Lower Permian, Ufimian, Solikamsk Horizon, Tyulkino locality; (3) Pseudopolycentropus janeannae: Middle Jurassic, Inner Mongolia, China, Jiulongshan Formation

Novokshonov and Sukacheva, 2001 (the latter the only species in this genus) were also excluded. Three fossil species, Permopanorpa inaequalis Tillyard, 1926 (Permopanorpidae) [37, 38], Protopanorpa longicubitalis Bashkuev, 2010 (Permochoristidae) [39], and Pseudopolycentropus janeannae Ren, Labandeira and Shih, 2010 (Pseudopolycentropodidae) [8] were selected as outgroups for the analysis (Tables 3 and 4). The outgroup selection was based on the phylogeny of basal panorpids in Grimaldi and Engel, 2005 [13], and the phylogeny of Aneuretopsychina

Table 4 Summary of the species excluded with reasons for exclusion

\begin{tabular}{ll}
\hline Excluded species & Reasons for exclusion \\
\hline Baissopsyche pura & Forewing venation not complete, key characters missing \\
Mesopsyche ordinata & Forewing width/length ratio at 0.48 much higher than that of all others (with typical ratio between \\
& 0.30 and 0.35 and two outliers at 0.27 and 0.38) \\
Mesopsyche justa & Base of forewing missing for holotype; inconsistent venation among holotype and paratypes. \\
Mesopsyche gentica & Base of forewing missing \\
Mesopsyche tortiva & Incomplete forewing and base of hind wing missing \\
Mesopsyche incompleta & Incomplete fore- and hind wings \\
Mesopsyche javorskii & Hind wing only \\
Mesopsyche tongchuanensis & Incomplete forewing only \\
Mesopanorpodes wianamattensis & Anal area of forewing missing \\
Permopsyche robustus & Incomplete forewing only \\
Mesoses optata & Incomplete forewing only \\
Mesoses magna & Incomplete forewing only \\
Mesoses gayndah & Incomplete forewing only \\
Ptychopteropsis mirabilis & Incomplete forewing only \\
Turanopsyche venosa & Incomplete hind wing only \\
Ferghanopsyche rotundata & Incomplete forewing only \\
\hline
\end{tabular}


[3] showing their relation to basal panorpids and extant mecopterans. We chose the type genus, Permopanorpa, of Permopanorpidae as the root of the tree, because it is more basal than all other families in Aneuretopsychina. The character-state matrix, consisting of 16 taxa and 26 morphological characters with two or more characterstates. This matrix is provided in Table 5 .

The character-state matrix was entered into WinClada (Version1.00.08) [40], a morphological analysis software program. Tree searches implemented a heuristic search method, with options set to hold 10,000 trees, 1000 replications, 100 starting tree replication, and a multiple TBR + TBR search strategy. All characters were treated as unordered and were weighted equally. Missing or inapplicable characters were coded with question marks. Parsimony analyses were performed by using NONA (Version 2.0) [41] and PAUP (Version 4.0b10) [42]. We conducted both parsimony versions because only one outgroup can be defined in the NONA but three outgroups are identified in PAUP, resulting in different heuristic searches used in these two programs.

For NONA, we use an exhaustive search option and bootstrap support values from 1000 replications are presented as numbers under branch nodes. For PAUP, the same matrix editing program was used, Nexus Data Editor (Version 5.0), and the NEX file was entered into PAUP which employs a general heuristic search with 1000 replicates and TBR branch swapping. All characters were treated as unordered and equally weighted.

\section{Geometric morphometric analysis of forewings}

We began our analyses by obtaining and compiling completed forewing samples from the literature, and then chose landmarks to identify their wing shape, relative positions of the branching points, and number of branches. The specimens, the same as those of the phylogenetic analyses, comprise 13 ingroups and three outgroups.

We used Adobe Photoshop CS5 and Adobe Illustrator CS6 to re-draw the venation of the 13 ingroups and three outgroups based on line drawings published in the literature (Fig. 1), with minor modifications and assumptions noted in the Fig. 1 caption. The drawings were entered into tps-UTILS [43] to convert the JPEG files into TPS files for further use. For the first set of analysis, 38 landmarks were placed using tps-DIG [44] on positions of key veins on the wings, four examples of which are shown in Fig. 2a-d. Compared to the venation of Vitimopsyche pristina sp. nov. (Fig. 2a), the outgroup Permopanorpa inaequalis (Fig. 2c) has an extra RS, two extra MA veins, and two extra MP veins and Protopanorpa longicubitalis (Fig. 1m) has an extra RS and three extra MP veins, while the outgroup Pseudopolycentropus janeannae (Fig. 2d) and the ingroup E. pentavenulosa (Fig. 2b) have an extra MP vein. To accommodate these

Table 5 Character state matrix of 26 characters for the 16 taxa included in the phylogenetic study

\begin{tabular}{|c|c|c|c|c|c|c|c|c|c|c|c|c|c|c|c|c|c|c|c|c|c|c|c|c|c|c|}
\hline \multirow[t]{2}{*}{ Taxa/ character } & \multicolumn{10}{|l|}{0} & \multicolumn{10}{|l|}{1} & \multicolumn{6}{|l|}{2} \\
\hline & 0 & 1 & 2 & 3 & 4 & 5 & 6 & 7 & 8 & 9 & 0 & 1 & 2 & 3 & 4 & 5 & 6 & 7 & 8 & 9 & 0 & 1 & 2 & 3 & 4 & 5 \\
\hline Permopanorpa inaequalis (Permopanorpidae) & 1 & 0 & 0 & 0 & 0 & 0 & 2 & 0 & 0 & 0 & 0 & 0 & 0 & 0 & 0 & 0 & 0 & 0 & 0 & 0 & 1 & 0 & 1 & 0 & 2 & ? \\
\hline Protopanorpa longicubitalis & 2 & 0 & 0 & 0 & 1 & 0 & 2 & 0 & 0 & 0 & 0 & 0 & 0 & 1 & 0 & 1 & 0 & 0 & 0 & 1 & 0 & 0 & 1 & $?$ & ? & ? \\
\hline \multicolumn{27}{|l|}{ (Permochoristidae) } \\
\hline Pseudopolycentropus janeannae & 0 & $?$ & 2 & 0 & 0 & 1 & 1 & 1 & 1 & 1 & 0 & 0 & 1 & 2 & 0 & 1 & 0 & $?$ & $?$ & 2 & 1 & 2 & 0 & 0 & U & 1 \\
\hline \multicolumn{27}{|l|}{ (Pseudopolycentropodidae) } \\
\hline Permopsyche rasnitsyni & 1 & 0 & 0 & 1 & 2 & 2 & 0 & 0 & 1 & 2 & 0 & 1 & 1 & 1 & 1 & 1 & 0 & 0 & 0 & 2 & 1 & 1 & 2 & ? & ? & ? \\
\hline Permopsyche issadensis & 1 & 1 & 0 & 1 & 1 & 2 & 0 & 0 & 1 & 2 & 0 & 1 & 1 & 1 & 1 & 1 & 0 & 0 & 0 & 2 & 1 & 1 & 2 & U & ? & ? \\
\hline Permopsyche belmontensis & 1 & 1 & 0 & 1 & 2 & 2 & 0 & 0 & 1 & 2 & 0 & 0 & 1 & 1 & 1 & 1 & 0 & 1 & 0 & 2 & 0 & 1 & 2 & ? & ? & ? \\
\hline Mesopsyche triareolata & 1 & 1 & 1 & 1 & 0 & 0 & 1 & 0 & 1 & 2 & 0 & 0 & 2 & 0 & 1 & 1 & 0 & 0 & 0 & 2 & 1 & 1 & 2 & ? & $?$ & ? \\
\hline Mesopsyche dobrokhotovae & 1 & 2 & 0 & 1 & 1 & 2 & 0 & 0 & 1 & 2 & 0 & 1 & 2 & 1 & 1 & 1 & 0 & 0 & 0 & 2 & 1 & 1 & 2 & $?$ & ? & ? \\
\hline Mesopsyche shcherbakovi & 2 & 0 & 0 & 1 & 1 & 2 & 0 & 0 & 1 & 2 & 0 & 1 & 1 & 1 & 0 & 0 & 0 & 0 & 0 & 1 & 1 & 1 & 2 & ? & ? & ? \\
\hline Lichnomesopsyche gloriae & 2 & 1 & 0 & 0 & 0 & 2 & 0 & 0 & 1 & 2 & 1 & 1 & 1 & 0 & 1 & 1 & 0 & 0 & 0 & 2 & 1 & 1 & 2 & 0 & 1 & 1 \\
\hline Lichnomesopsyche daohugouensis & 2 & 1 & 0 & 0 & 1 & 2 & 0 & 0 & 1 & 2 & 1 & 1 & 1 & 0 & 1 & 1 & 1 & 0 & 0 & 2 & 1 & 1 & 2 & 0 & 1 & 1 \\
\hline Lichnomesopsyche prochorista & 2 & 1 & 0 & 0 & 2 & 2 & 0 & 0 & 1 & 2 & 1 & 1 & 1 & 0 & 1 & 1 & 0 & 0 & 0 & 2 & 1 & 1 & 2 & 0 & 1 & 1 \\
\hline Epicharmesopsyche pentavenulosa & 2 & 0 & 0 & 1 & 0 & 0 & 0 & 1 & 1 & 1 & 0 & 1 & 0 & 2 & 1 & 1 & 1 & $?$ & $?$ & $?$ & $?$ & 2 & 2 & 2 & 0 & 0 \\
\hline Vitimopsyche pristina & 2 & 0 & 0 & 1 & 0 & 0 & 0 & 0 & 1 & 2 & 2 & 1 & 1 & 1 & 1 & 1 & 0 & 0 & 1 & 1 & 2 & 1 & 2 & 1 & ? & 1 \\
\hline Vitimopsyche torta & 2 & 0 & 1 & 1 & 0 & 0 & 0 & 0 & 1 & 2 & 2 & $?$ & 1 & 1 & 1 & 1 & 0 & 0 & 0 & 1 & 2 & 1 & 2 & ? & ? & ? \\
\hline Vitimopsyche kozlovi & 2 & 0 & 0 & 1 & 0 & 0 & 0 & 0 & 1 & 2 & 2 & 1 & 1 & 1 & 1 & $?$ & 0 & 0 & 1 & 1 & $?$ & 1 & 2 & 0 & 2 & 1 \\
\hline
\end{tabular}

The "?" denotes that the state is unknown or is inapplicable 


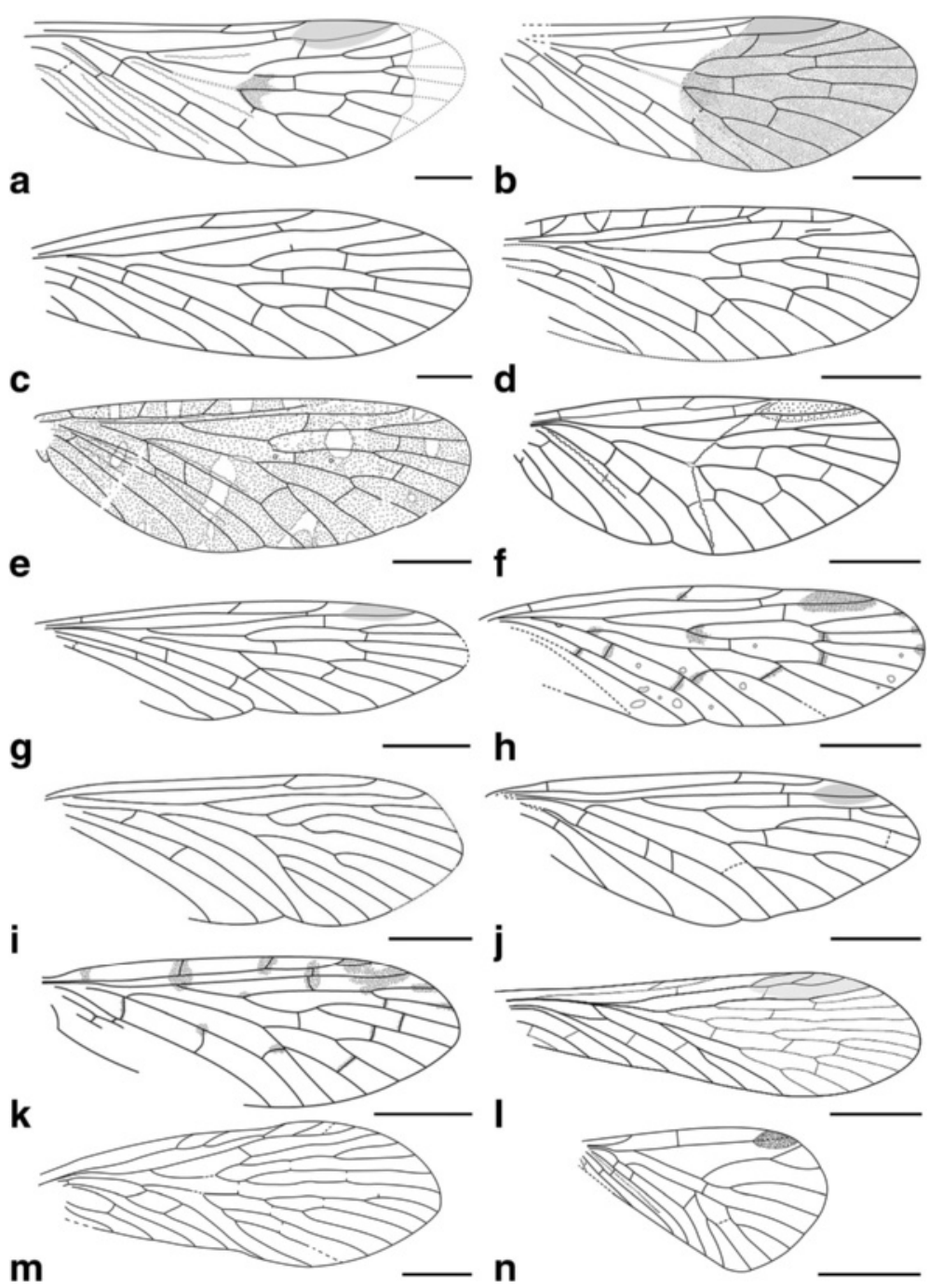

Fig. 1 Line drawings of forewing samples for 14 representative species used in analyses. a Permopsyche rasnitsyni, from Bashkuev, 2011 [22]. b Permopsyche issadensis, from Bashkuev, 2011 [22]. c Permopsyche belmontensis, from Riek, 1953 [16] and Bashkuev, 2011 [22]. d Mesopsyche triareolata, from Bashkuev, 2011 [22] and Lambkin, 2014 [24]. e Mesopsyche dobrokhotovae, from Novokshonov, 1997 [18] and Bashkuev, 2011 [22]. f Mesopsyche shcherbakovi, from Novokshonov, 1997 [18]. g Lichnomesopsyche gloriae, from Ren, Labandeira, and Shih, 2010 [21]. h Lichnomesopsyche daohugouensis, from Ren, Labandeira, and Shih, 2010 [21]. i Epicharmesopsyche pentavenulosa, from Shih, Qiao, Labandeira, and Ren, 2013 [23]. $\mathbf{j}$ Vitimopsyche kozlovi from Ren, Labandeira, and Shih, 2010 [21] (one crossvein [between MP2 and MP3] estimated using other two species of the same genus). k Vitimopsyche torta, from Novokshonov and Sukacheva, 2001 [19] (two landmarks [for endings of 1A and 2A] estimated using average of the other two species of the genus). I Permopanorpa inaequalis, from Beckemeyer and Hall, 2007 [51]. m Protopanorpa longicubitalis, from Bashkuev, 2010 [39]. n Pseudopolycentropus janeannae, from Ren et al., 2010 [8]. Scale bars represent $5 \mathrm{~mm}$ in (e) and $(\mathbf{g}-\mathbf{m}), 1 \mathrm{~mm}$ in $(\mathbf{a}-\mathbf{c})$, and $3 \mathrm{~mm}$ in (d), (f) and (n)

additional veins, we applied additional landmarks to each extra vein for representation (Fig. 2b-d). For all other wings that lack these extra veins, we simply doubled or occasionally tripled the number of landmarks as shown in Fig. 2a. A consensus was calculated by using all 16 samples and 38 landmarks in tps-SUPER [45]. Later, using the consensus as the "reference" and all sixteen samples as the "data", we used tps-SPLIN [46] to calculate the Procrustes distances [47]. We converted the data into NTS files to complete the final step in
NTedit where a matrix was produced and labeled. We entered this matrix into NTSYSpc [48], where we used an unweighted pair-group method using arithmetic averages (UPGMA) to produce the first known tree showing the phenetic relationships among these 16 scorpionfly wing samples based on 38 landmarks.

To conduct a more detailed analysis, we ran the above program again by adding positions of two crossveins with 42 landmarks (Fig. 3a-d). Because E. pentavenulosa does not have any of these crossveins, we decided to 


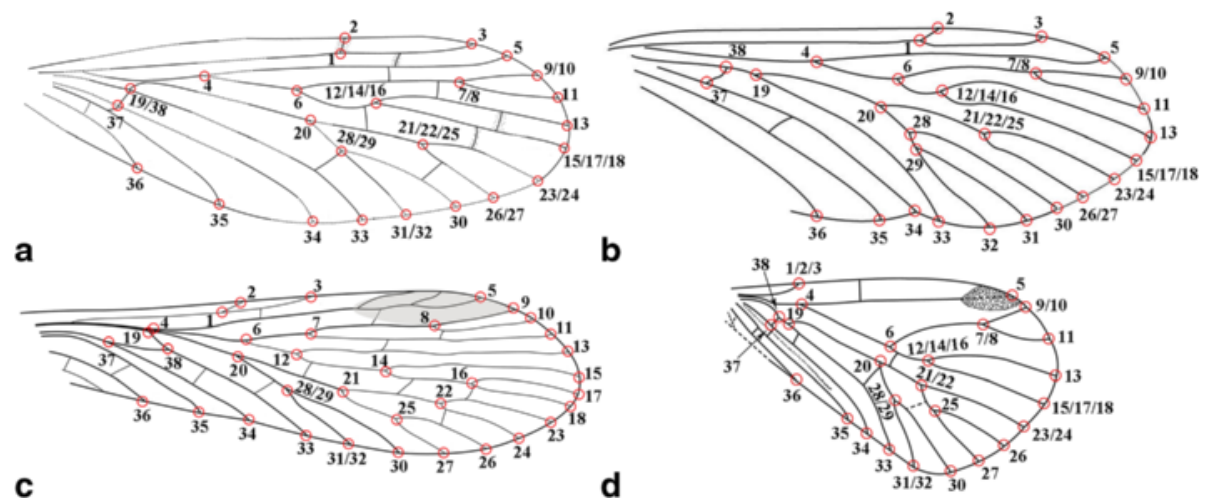

Fig. 2 The landmark numbers of the four forewing samples for the case of 38 landmarks. a Vitimopsyche pristina sp. nov. (original). b Epicharmesopsyche pentavenulosa, from Shih, Qiao, Labandeira, and Ren, 2013 [23]. c Permopanorpa inaequalis, R. J. Tillyard, 1926 [37]. d Pseudopolycentropus janeannae, from Ren et al., 2010 [8]. Not to scale

exclude this taxon from this set of analyses. The $15 \mathrm{im}-$ ages of 12 ingroups and three outgroups subsequently were entered into tps-UTILS, marked in tps-DIG, averaged in tps-SUPER, calculated in tps-SPLIN, and transferred to the second tree in NTSYSpc, using the same procedures mentioned above.

\section{Ethics statement}

The authors declare that the study makes no uses of human, clinical tools and procedures, vertebrate and regulated invertebrate animal subjects and/or tissue, and plants.

\section{Results}

\section{Systematic paleontology}

Family Mesopsychidae Tillyard, 1917.

Type genus: Mesopsyche Tillyard, 1917.

Lichnomesopsyche Ren, Labandeira and Shih, 2010 [21].

Type species: Lichnomesopsyche gloriae Ren, Labandeira and Shih, 2010 [21].
Included species: Type species, Lichnomesopsyche daohugouensis Ren, Labandeira and Shih, 2010, and the new species described herein.

\section{Emended diagnosis}

In forewing, both Rs and MA with two endings, not always forking at the same level. The MP bifurcation is slightly proximal of Rs + MA bifurcation, or both forking at the same level. In the hind wing, MP originates from the stem of MP $+\mathrm{CuA}$ slightly distal or proximal of the Rs + MA originating from R1.

Lichnomesopsyche prochorista $\mathrm{sp}$. nov.

urn: lsid:zoobank.org:act:0C5A060A-9314-4752-94FE35B65B18A132

\section{Diagnosis}

The new species resembles Lichnomesopsyche gloriae and $L$. daohugouensis in venational features, but differs from both by Rs forking proximal of the MA bifurcation on the fore- and hind wings. It also differs from $L$.
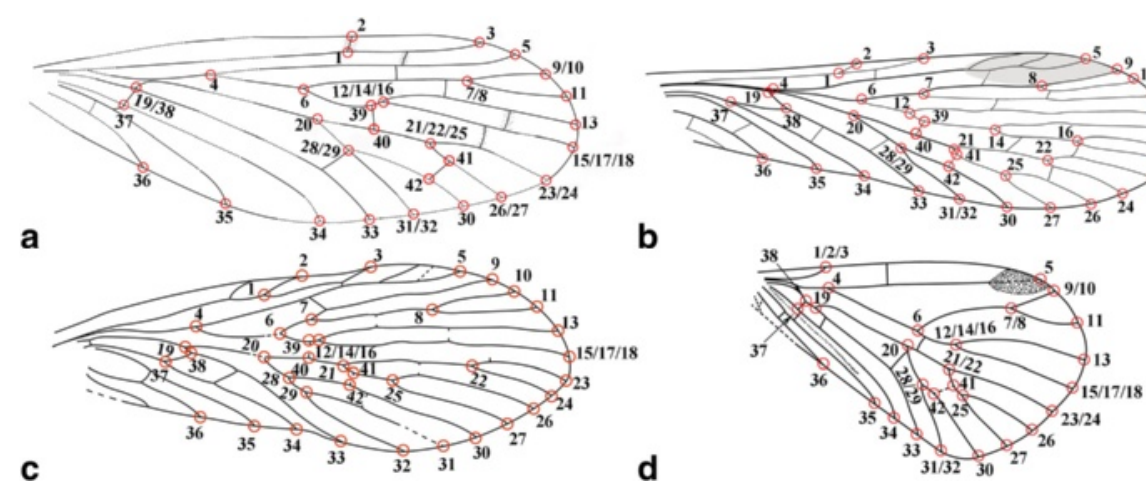

Fig. 3 The landmark numbers of the four forewing samples for the case of 42 landmarks. a Vitimopsyche pristina sp. nov. (original). b Permopanorpa inaequalis, R. J. Tillyard (1926) [37]. c Protopanorpa longicubitalis, from Bashkuev (2010) [39]. d Pseudopolycentropus janeannae, from Ren et al. (2010) [8]. Not to scale 
daohugouensis by not having spots on the fore- and hind wings.

\section{Etymology}

The specific name is a combination of Latin "pro-" (before) and the Greek "choristos" (separate), indicating that the forking of Rs vein is proximal of the MA vein bifurcation.

\section{Holotype}

Specimen CNU-MEC-NN-2015002p/c, part and counterpart (Figs. 4 and 5) is an almost complete specimen with well-preserved body and wings; female. Forewing length $24.6 \mathrm{~mm}$, width $7.5 \mathrm{~mm}$; body length (excluding antennae and proboscis) $22.2 \mathrm{~mm}$; proboscis length at least $9.7 \mathrm{~mm}$; antenna length (as preserved) at least $4.8 \mathrm{~mm}$.

\section{Paratypes}

Specimen CNU-MEC-NN-2015008, a well-preserved individual showing the complete insect in dorsal view (Fig. 6); male. Forewing length at least $25.9 \mathrm{~mm}$, width about $7.7 \mathrm{~mm}$; body length (as preserved, excluding antennae and proboscis) $23.5 \mathrm{~mm}$; proboscis length (as preserved) at least $7.1 \mathrm{~mm}$; antenna length at least $4.6 \mathrm{~mm}$.

Specimen CNU-MEC-NN-2015001p/c, part and counterpart (Fig. 7a, b, c), with a partially preserved body and well-preserved wings, showing the insect in dorsal view; sex unknown. Forewing length $22.4 \mathrm{~mm}$, width $7.7 \mathrm{~mm}$.

Specimen CNU-MEC-NN-2015016p/c, part and counterpart (Fig. 7d, e, f), an almost complete individual showing the body and one side of the wings; sex unknown. Forewing length $22.0 \mathrm{~mm}$, width $8.3 \mathrm{~mm}$; body length (excluding antennae and proboscis) $24.2 \mathrm{~mm}$; proboscis length at least $10.6 \mathrm{~mm}$; antenna length (as preserved) at least $5.7 \mathrm{~mm}$.
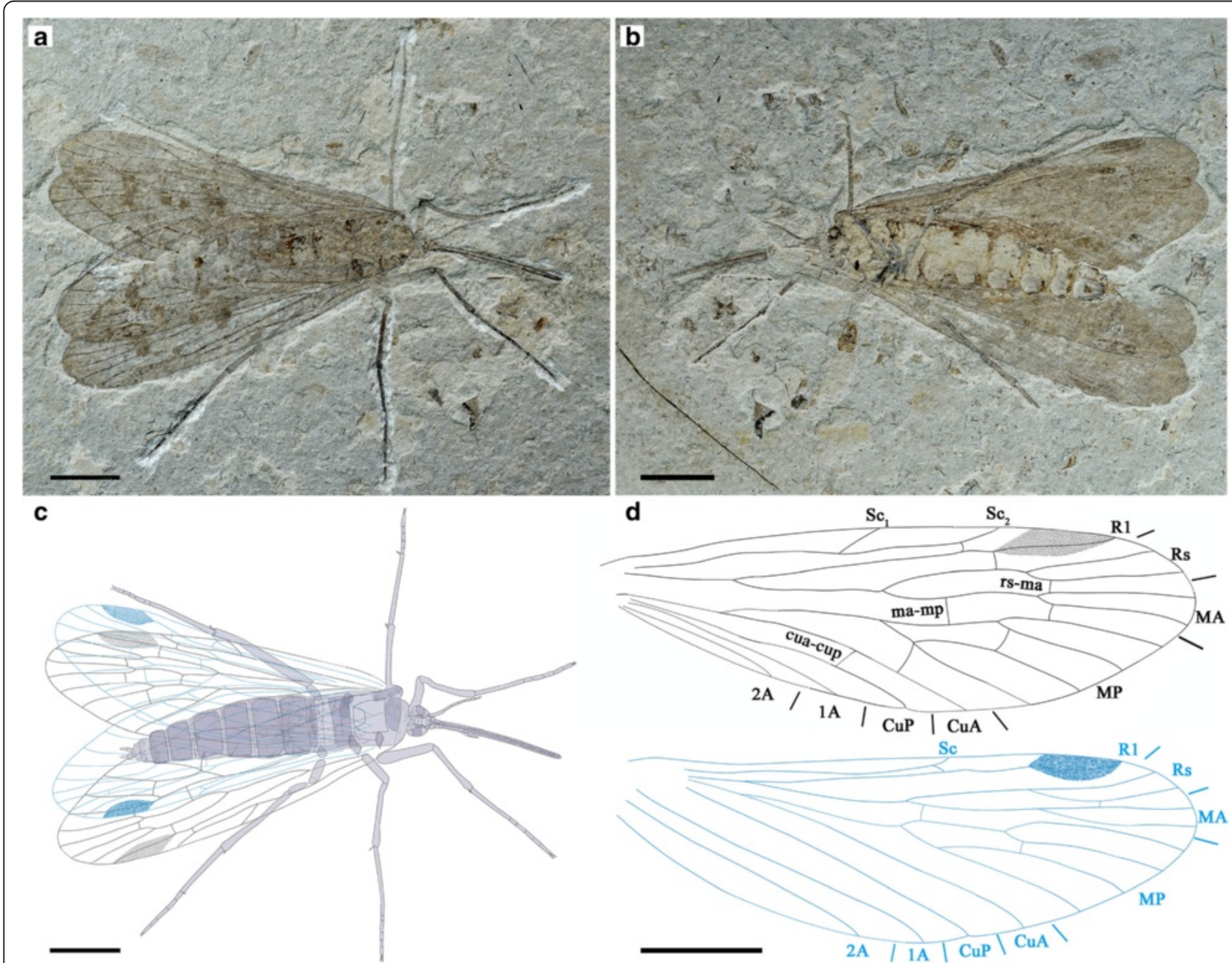

Fig. 4 Lichnomesopsyche prochorista sp. nov., holotype specimen CNU-MEC-NN-2015002p/c. a Photograph of part. b Photograph of counterpart. c Overlay drawing of part. $\mathbf{d}$ Line drawings of right fore and hind wings. Scale bars represent $5 \mathrm{~mm}$ in (a-d) 

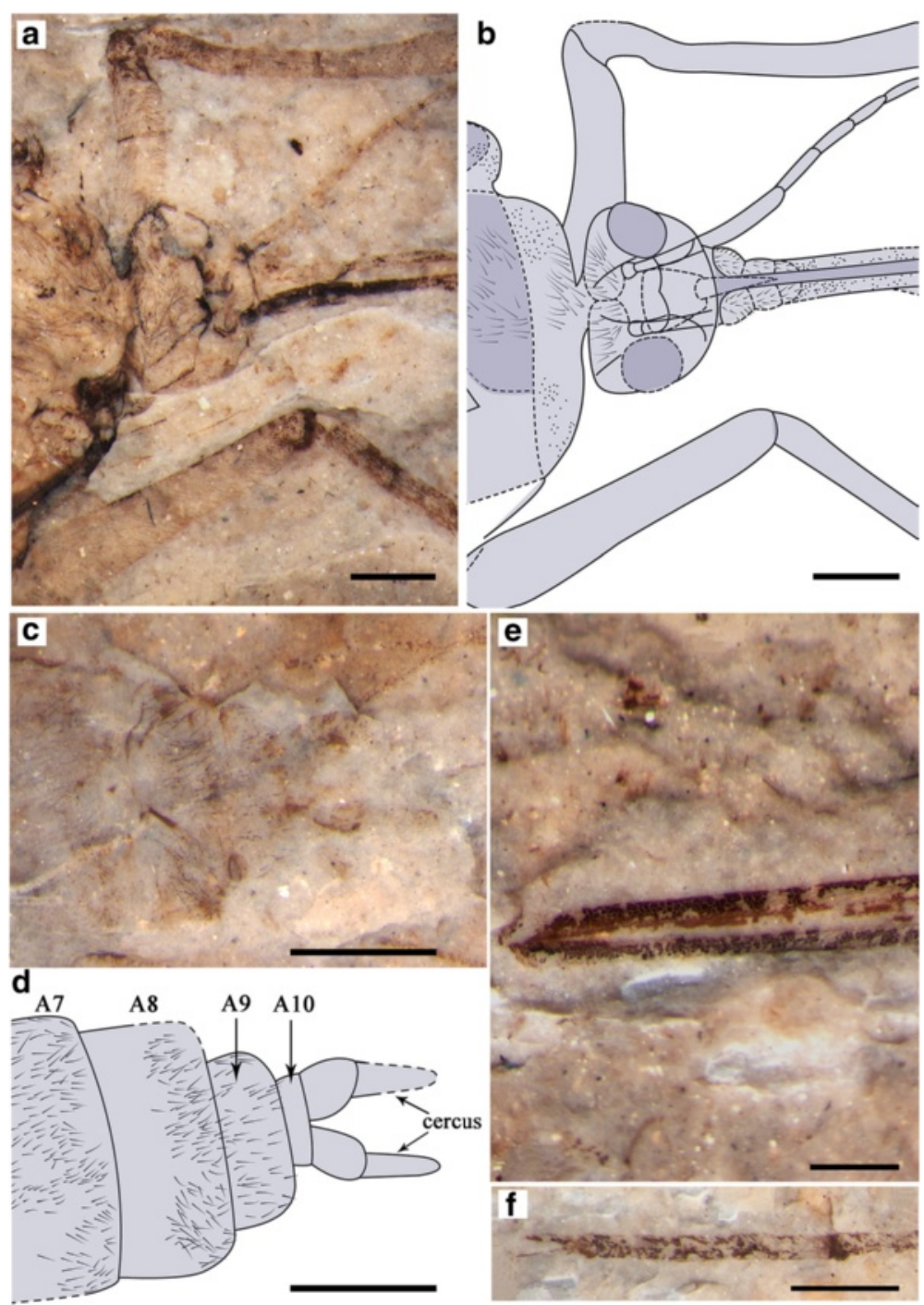

Fig. 5 Detail structures of Lichnomesopsyche prochorista sp. nov., holotype specimen CNU-MEC-NN-2015002p. a Photograph under ethanol of head and antennae. b Overlay drawing of the head and antennae. c Photograph of genitalia with vestiture in dorsal view, under alcohol. d Overlay drawing of female genitalia in dorsal view. e Photograph under ethanol of the proboscis base. $\mathbf{f}$ Photograph under ethanol of tarsi and associated two claws of right foreleg. Scale bars represent $1 \mathrm{~mm}$ in (a-d) and (f), $0.5 \mathrm{~mm}$ in (e). Corresponding abbreviations are: A7: the seventh segment of the abdomen; A8: the eighth segment of the abdomen; A9: the ninth segment of abdomen; A10: the tenth segment of the abdomen

\section{Locality and stratigraphic horizon}

The specimens were collected near Daohugou Village, Shantou Township, Ningcheng County, in Inner Mongolia of Northeastern China (N41 $18.979^{\prime}$, E119 $\left.14.318^{\prime}\right)$. The stratigraphic position of the examined material is the Jiulongshan Formation, the late Callovian Stage of the latest Middle Jurassic (164-165 Mya), determined by a ${ }^{40} \mathrm{Ar} /{ }^{39} \mathrm{Ar}$ isotopic age date [49] calibrated to a standard international time scale $[49,50]$. The locality and stratigraphic horizon are the same for all other new specimens described herein.

\section{Description}

Female (based on holotype specimen CNU-MEC-NN2015002p/c).

Complete insect (Figs. 4 and 5) with well-preserved wings and body.

Head: Triangular in dorsal view, prognathous. Eyes large, widely separated. Proboscis long and slightly curved, apical pseudolabellae absent [3]. Proboscis covered with dense setae or microtrichia but lacking annuli. Antennae distinctly shorter than proboscis, flagellum multiarticulate and filiform, gradually tapering (Fig. 5a, b, e). 


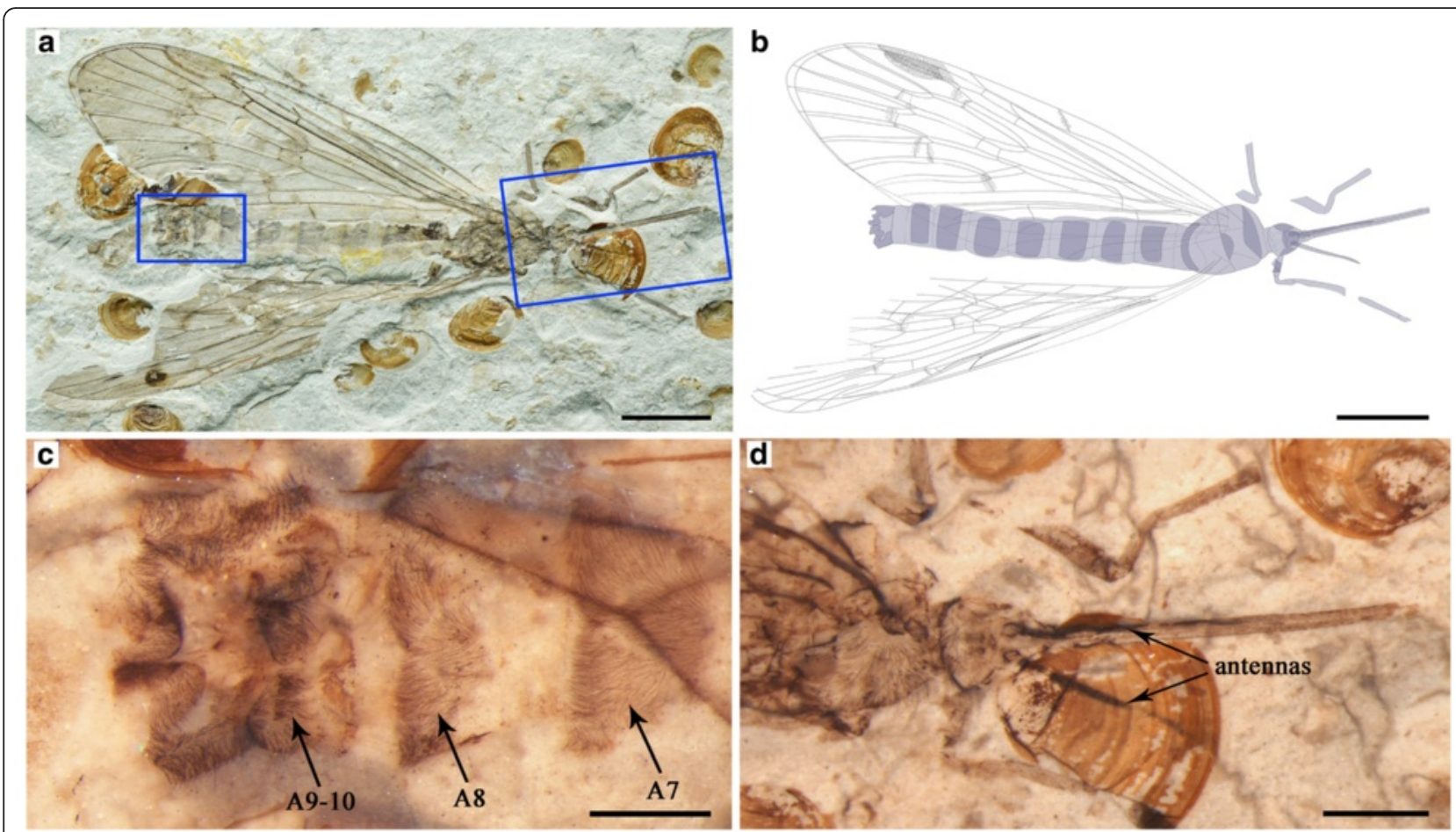

Fig. 6 Lichnomesopsyche prochorista sp. nov., paratype specimen CNU-MEC-NN-2015008. a Photograph of specimen. b Overlay drawing of habitus. c Photograph under ethanol of male genitalia with vestiture in dorsal view. $\mathbf{d}$ Photograph under ethanol of head and part of thorax in dorsal view. Scale bars represent $5 \mathrm{~mm}$ in (a) and (b), $1 \mathrm{~mm}$ in (c), and $2 \mathrm{~mm}$ in (d). Corresponding abbreviations are: A7: the seventh segment of the abdomen; A8: the eighth segment of the abdomen; A9-10: the nine to tenth segments of the abdomen

Thorax: Pronotum small, meso- and metanotum large, more or less similar to each other. Scutum distinct, but with an indistinct scutellum (Fig. 4c).

Legs: Legs entirely covered with annulated pubescence. The femora of the mid- and hind legs narrow, elongated, with one apical spur. Tibiae long and slender, with one apical spur. Tarsi 5-segmented, pretarsus with two claws (Fig. 5f).

Wings: Forewing slender (length/width ratio 3.3:1), apical margin round. Membrane delicate. Sc long, but not extending beyond the MA bifurcation, with only one inclined anterior branch. Pterostigma distinct. Both Rs and MA with two branches. MP bifurcation slightly proximal to the MA + Rs bifurcation, with four long branches. 1A and $2 \mathrm{~A}$ well developed. Hind wing almost the same as forewing in shape, but slightly smaller and broader (length/width ratio 3.1:1). Sc distinctly short, lacking anterior branches. R1 entering pterostigma, smooth and curved. Pterostigma well defined. The details of the wings are depicted in Fig. 4d.

Abdomen: Female abdomen elongate, tapering apically, with 10 visible segments. Segments 3-7 distinctly long. Segments 8-10 more slender than 2-6, without an enlarged genital bulb (Fig. 5c, d). Cerci at least 2-segmented, arising from the segment 10 . Basal segments of cerci not fused with each other (Fig. 4c).
Male: (based on paratype specimen CNU-MEC-NN2015008, Fig. 6).

Head: Triangular in dorsal view. Proboscis straight and siphonate, covered with dense setae. Antennae filiform, shorter than proboscis.

Thorax and Legs: Pronotum small. Meso- and metanotum large, scutum and scutellum indistinct on part and counterpart. A slender right foreleg and parts of left legs are preserved.

Wings: Forewing slightly broader (length/width ratio 3.4:1), with wing venation the same as female. Hind wings almost the same as forewings in shape, but slightly smaller and broader (length/width ratio 3.3:1).

Abdomen: Elongate, with nine visible segments. The first segment closely associated with the metathorax. Segments 2 to 8 normal; nine and ten enlarged, bulbous (Fig. 6c).

Lichnomesopsyche daohugouensis Ren, Labandeira and Shih, 2010, p. 723, Fig. 5; p. 730, Plate IV. Holotype: No. CNU-MEC-NN-2005022p/c [21].

\section{Revised diagnosis}

Hind wing Sc distinctly short; lacking anterior branches. Rs and MA almost forking at the same level. MP forking slightly proximal of the MA+ Rs bifurcation. Thyridium not always evident on both forewings and hind wings. 

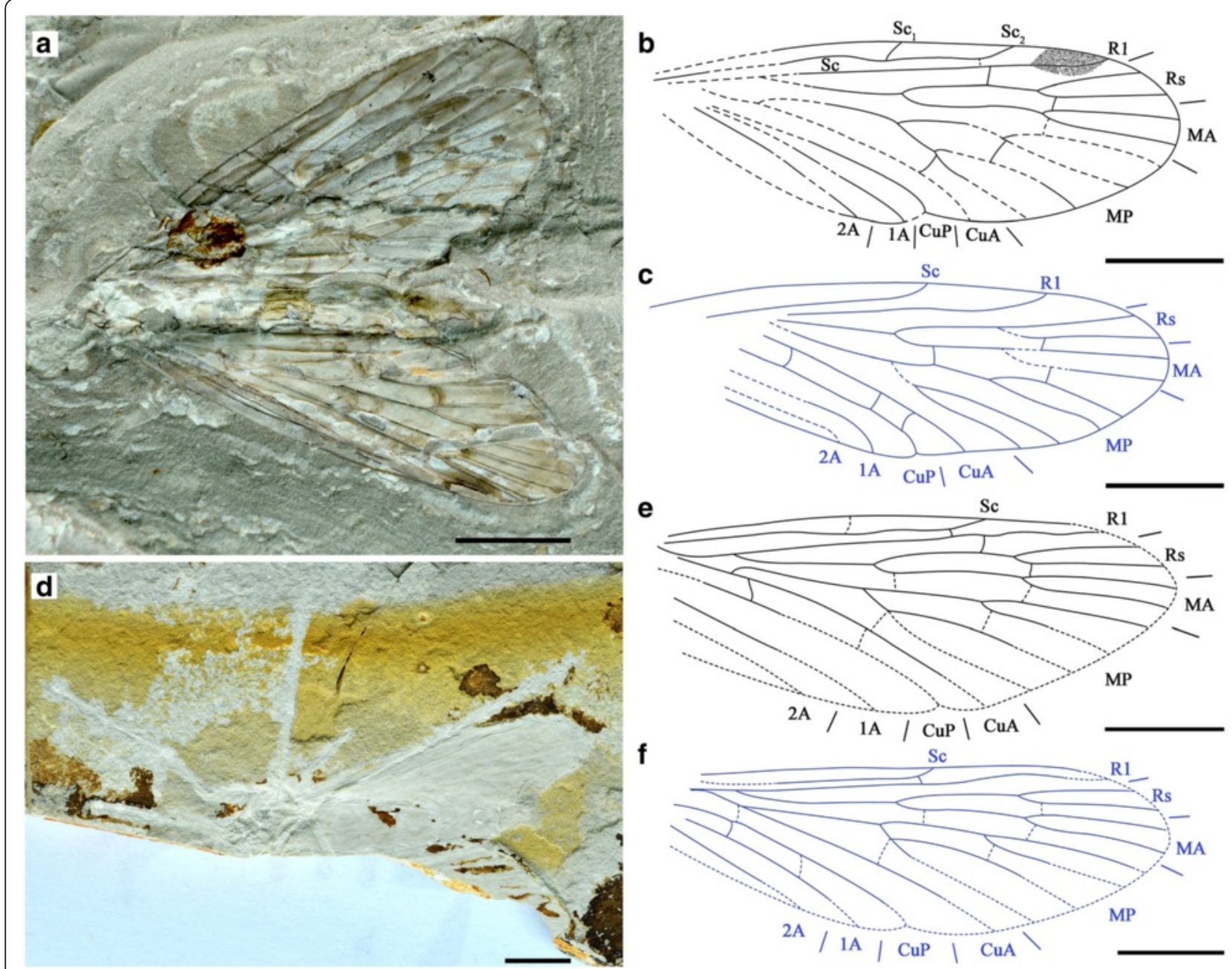

Fig. 7 Lichnomesopsyche prochorista sp. nov., paratype specimens CNU-MEC-NN-2015001p/c and CNU-MEC-NN-2015016p/c. Specimen CNU-MEC-NN-2015001 p: a Photograph of part. b Overlay drawing of right forewing. c Overlay drawing of right hind wing. Specimen CNU-MEC-NN-2015016p: d Photograph of part. e Overlay drawing of right forewing. f Overlay drawing of right hind wing. Scale bars represent $5 \mathrm{~mm}$ in (a-f)

\section{Additional specimens}

Specimen CNU-MEC-NN-2015003p/c; female, part and counterpart (Fig. 8). Forewing length $21.9 \mathrm{~mm}$, width $7.0 \mathrm{~mm}$; body length (excluding proboscis) at least $23.3 \mathrm{~mm}$; proboscis length at least $6.9 \mathrm{~mm}$.

Specimen CNU-MEC-NN-2015011p/c; male, part and counterpart (Fig. 9). Forewing length $23.2 \mathrm{~mm}$, width $7.8 \mathrm{~mm}$; body length (excluding proboscis and antennae) at least $22.7 \mathrm{~mm}$; proboscis length at least $4.4 \mathrm{~mm}$.

Specimen CNU-MEC-NN-2015007p/c; female, part and counterpart (Additional file 2: Figure S2). Forewing length $26.4 \mathrm{~mm}$, width $8.3 \mathrm{~mm}$; body length (excluding proboscis) at least $27.4 \mathrm{~mm}$; proboscis length at least $11.3 \mathrm{~mm}$.

Specimen CNU-MEC-NN-2015014; sex unknown (Additional file 3: Figure S3 A, C and D). Forewing length $24.5 \mathrm{~mm}$, width $7.0 \mathrm{~mm}$; body length (as preserved, excluding proboscis) at least $21.4 \mathrm{~mm}$; proboscis length at least $9.0 \mathrm{~mm}$.

Specimen CNU-MEC-NN-2015013; sex unknown (Additional file 3: Figure S3 B). Forewing length $26.8 \mathrm{~mm}$, width $7.7 \mathrm{~mm}$; body length (as preserved, excluding proboscis) at least $25.8 \mathrm{~mm}$; proboscis length at least $10.8 \mathrm{~mm}$.

\section{Description}

(Based on additional specimens CNU-MEC-NN2015003p/c, and CNU-MEC-NN-2015011p/c.)

Head: Small and triangular in dorsal view, prognathous. Eyes large, widely separated. Proboscis long and slightly curved at base. Antennae shorter than proboscis, filiform.

Legs: Densely clothed with short setae, never bearing transverse rows of annuli. Coxae and trochanter well-preserved. Femora stout. Tibiae long and slender, 

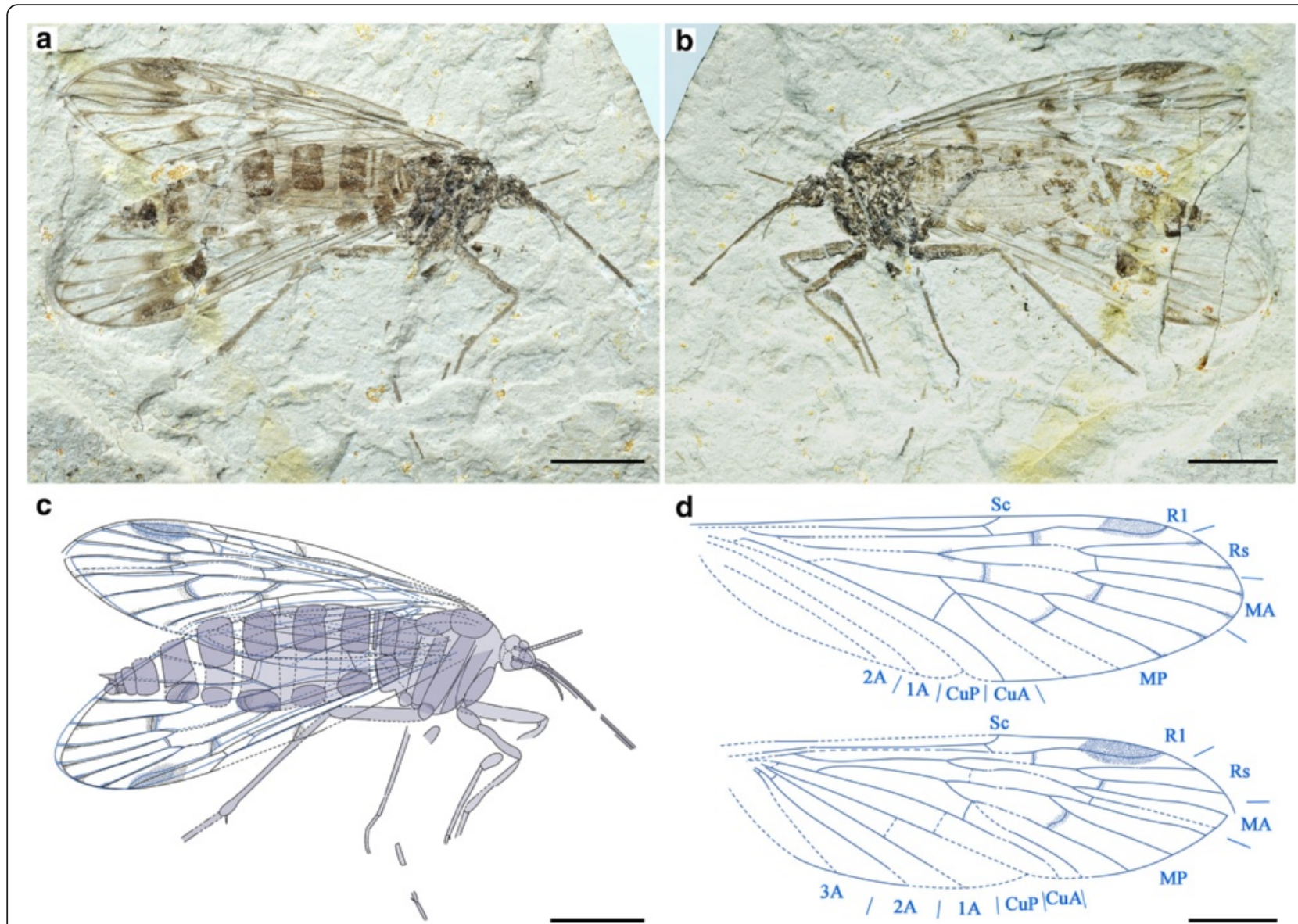

Fig. 8 Lichnomesopsyche daohugouensis Ren, Labandeira and Shih, 2010, new specimen CNU-MEC-NN-2015003p/c. a Photograph of part. b Photograph of counterpart. c Overlay drawing of part. d Overlay drawings of hind wings. Scale bars represent $5 \mathrm{~mm}$ in $(\mathbf{a}-\mathbf{c}), 3 \mathrm{~mm}$ in $(\mathbf{d})$

with one apical spur. Tarsi 5-segmented, pretarsus with two claws.

Wings: Forewing slender (length/width ratio 3.2:1), apical margin rounded. Thyridium not evident. Color pattern well developed around crossveins. Sc long, not extending beyond the MA bifurcation, with only one inclined to anterior branch. Pterostigma distinct. Rs and MA almost forking at the same level, both with two branches. MP bifurcation almost at the same level with MA + Rs bifurcation, MP with four long branches. $1 \mathrm{~A}$ and $2 \mathrm{~A}$ well developed. Hind wing almost the same as forewing in size and shape, but broader (length/width ratio 3:1). Sc distinctly short, lacking anterior branches. Pterostigma distinct. Rs and MA both with two branches; MP with 4 long branches. $1 \mathrm{~A}$ and $2 \mathrm{~A}$ well developed. The details of the wing venation depicted in Figs. 8d and 9d.

Abdomen: Female (based on additional specimen CNUMEC-NN-2015003p/c, Fig. 8a-c) abdomen elongate, tapering apically, with 10 visible segments. The first segment fused with metathorax. Segments 3-7 distinctly longer than others. Segments 8-10 more slender than 2-
6, without enlarged genital bulb. Cerci at least 2-segmented, arising from the segment 10. Basal segments of cerci not fused with each other.

Male (based on additional specimen CNU-MEC-NN2015011 p/c, Fig. 9a-c) abdomen elongate, with nine visible segments; the first one closely associated with the metathorax. The 2-8 segments slender, 9-11 are enlarged, bulbous.

Vitimopsyche Novokshonov and Sukatsheva, 2001 [19].

Type species. Vitimopsyche torta Novokshonov and Sukatsheva, 2001 [19].

Included Species: Type species, V. kozlovi Ren, Labandeira and Shih, 2010 [21] and the new species described herein.

\section{Emended diagnosis}

In forewing, Sc extends to $\mathrm{C}$ beyond the MA bifurcation, some individuals even beyond the Rs bifurcation, with one located anterior. Rs forking considerably more distal of the MA bifurcation, each with two branches. MP originates from the $\mathrm{MP}+\mathrm{CuA}$ much more proximal of the Rs + MA originating from R1. In the hind wing, Sc 


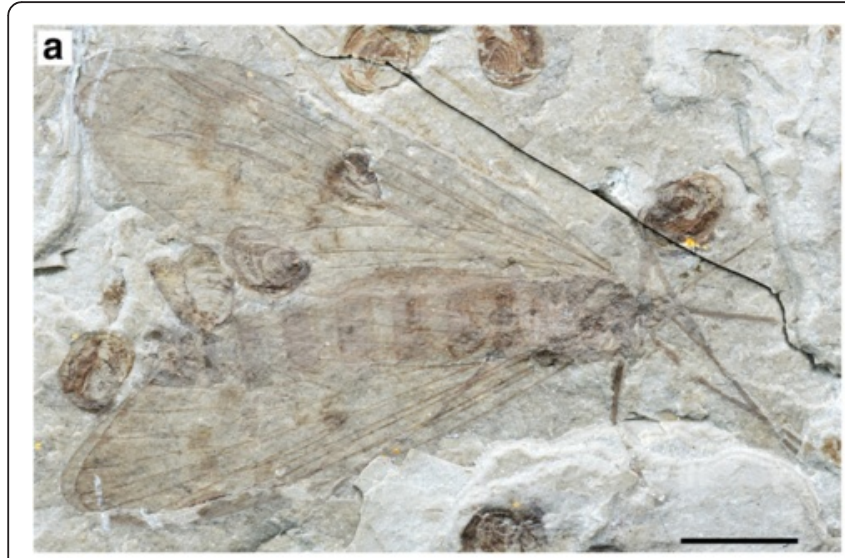

c

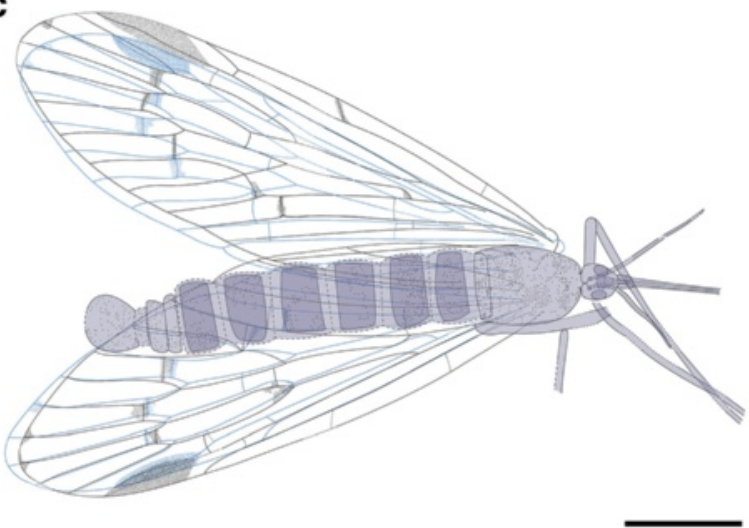

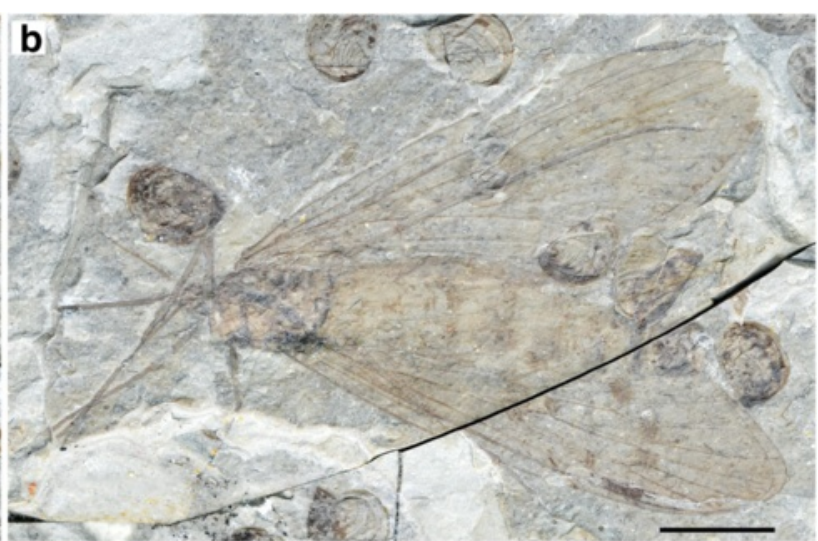

d

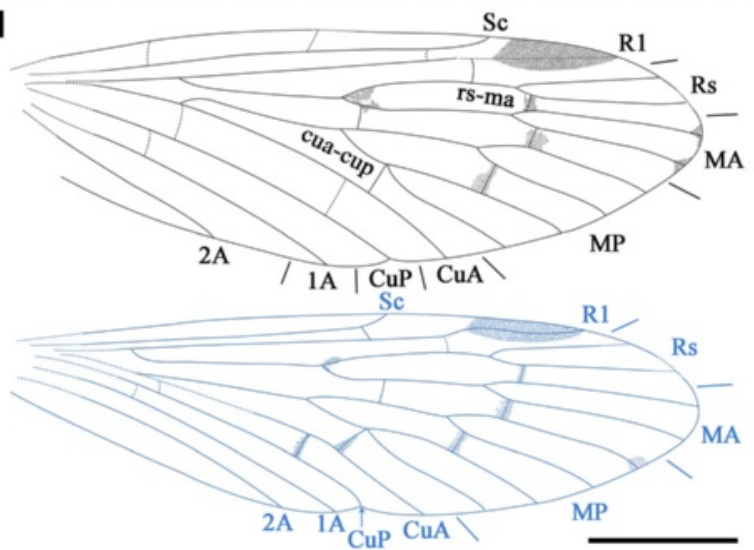

Fig. 9 Lichnomesopsyche daohugouensis Ren, Labandeira and Shih, 2010, new specimen CNU-MEC-NN-2015011p/c. a Photograph of part. b Photograph of counterpart. c Overlay drawing of part. d Overlay drawings of right fore and hind wings. Scale bars represent 5 mm in $(\mathbf{a}-\mathbf{d})$

short, reaching $\mathrm{C}$ not beyond the MA bifurcation. MP originating from the MP + CuA slightly distal or proximal of the Rs + MA from R1.

Vitimopsyche pristina sp. nov.

urn: lsid:zoobank.org:act:9942EAC8-55CB-4D8C-90A B-0127559BA8FC

\section{Etymology}

The specific name pristina originates from the Latin, pristinus, meaning "primordial", which refers to the geological time interval of occurrence of the new species is earlier than other species in this genus.

\section{Diagnosis}

The new species resembles $V$. torta and $V$. kozlovi in venational features, but is distinguished from them by the Sc reaching to the $\mathrm{C}$ beyond the Rs bifurcation in the forewing; and the hind wing MP originating from stem of the MP + CuA distal of Rs + MA from R1. It also differs from $V$. torta by the Sc with only one anterior branch in forewing.

\section{Holotype}

Specimen CNU-MEC-NN-2015009 of one individual with partly preserved body and wings; female. Forewing length $18.7 \mathrm{~mm}$, width $6.2 \mathrm{~mm}$; proboscis length (as preserved) is $4.5 \mathrm{~mm}$.

\section{Description}

The specimen has only one side of the wings preserved (Fig. 10a, b), while the fore- and hind wings are overlapping.

Head: Triangular in dorsal view, prognathous. Antennae unknown; eyes not well preserved. Frons and clypeus not noticeable. Proboscis incomplete; lacking fine annuli of microtrichia, pseudolabellae not present (Fig. 10c).

Thorax: Not discernible.

Legs: Slender, incompletely preserved.

Wings: Forewing broadened (length/width ratio: 3.0). Membrane delicate. Sc long, reaching $C$ beyond Rs bifurcation, not forking terminally, with only one anterior branch. R1 single, slightly curved near its ending. Pterostigma not well preserved. Both Rs and MA with two branches; MA stem and $\mathrm{MA}_{1}$ branch forming a 


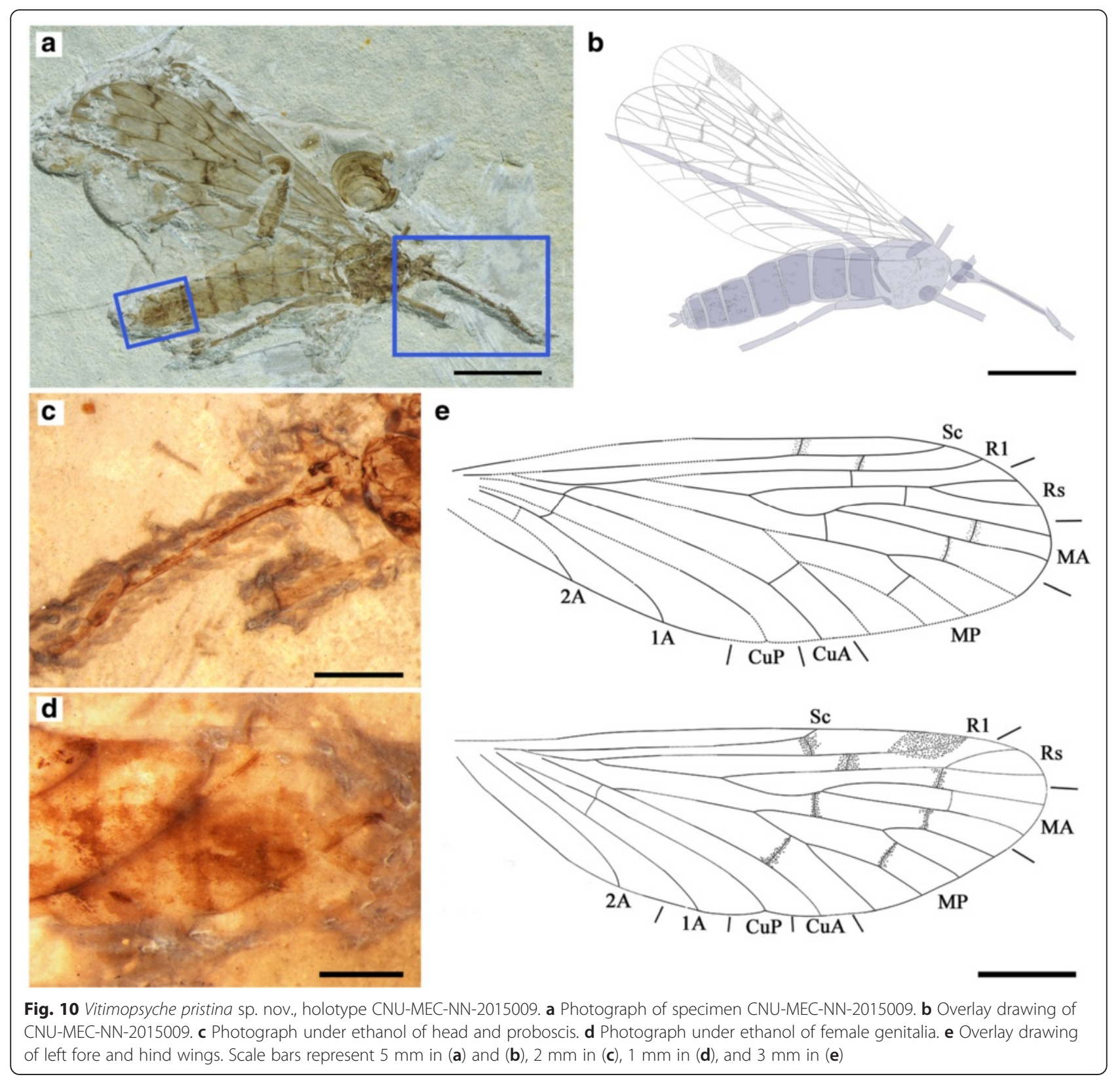

distinct S-shape; one cross-vein between $\mathrm{MA}_{1}$ and $\mathrm{MA}_{2}$. MP with four long branches, $\mathrm{MP}_{1+2}$ forking distal to $\mathrm{MP}_{3+4}$ bifurcation. Thyridium not evident. $\mathrm{CuA}$ and $\mathrm{CuP}$ single; $1 \mathrm{~A}$ and $2 \mathrm{~A}$ single and well developed; one crossvein between $\mathrm{CuP}$ and $1 \mathrm{~A}$, and one between $1 \mathrm{~A}$ and $2 \mathrm{~A}$.

Hind wing almost the same as forewing in shape but smaller. Right hind wing length $19.5 \mathrm{~mm}$, width $6.2 \mathrm{~mm}$; length/width ratio 3.2. Sc short, forking and reaching $C$ at about the same level of the MA bifurcation, lacking anterior branches. Pterostigma well defined. MP originating from the stem of MP + CuA distal of the Rs + MA originating from R1 (Fig. 10e).
Abdomen: Elongate, tapering apically, with 10 visible segments. The first segment fused with metathorax, Segments 8-10 more slender than segments 2-6, without an enlarged genital bulb (Fig. 10d).

\section{Results of phylogenetic analysis}

The maximum parsimony analysis by NONA yielded only one most parsimonious tree (Fig. 11a; tree length = 70 steps, consistency index $(\mathrm{CI})=0.60$, retention index $(\mathrm{RI})=0.68)$. Morphological characters were optimized with parsimony on the most parsimonious tree, showing only unambiguous changes. The bootstrap value results are shown in Fig. 11a. 


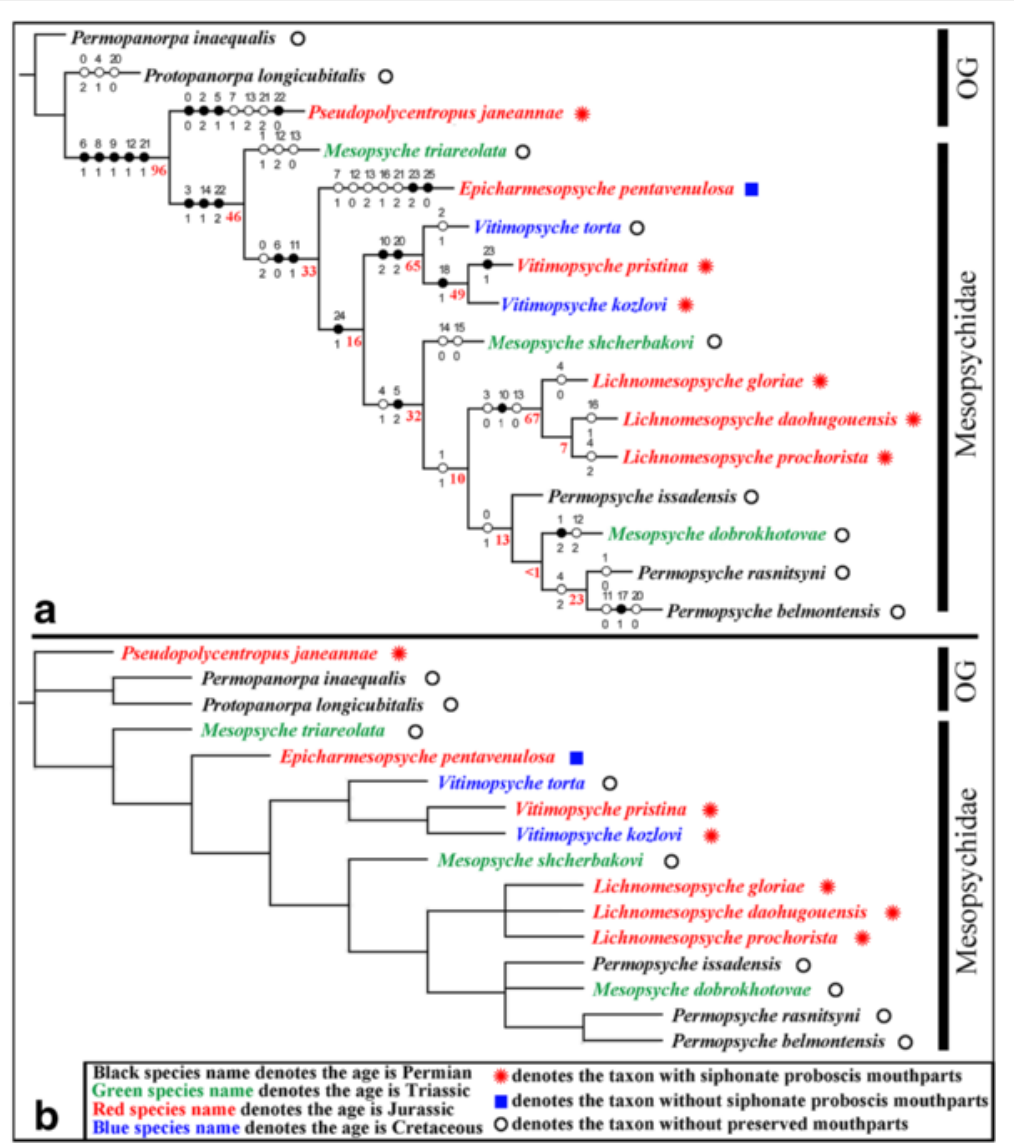

Fig. 11 Results of phylogenetic analyses (NONA and PAUP). a The most parsimonious tree with bootstrap support by NONA. b The consensus tree by PAUP. White circles indicate homoplasious characters, and the black circles indicate non-homoplasious characters. The numbers above branches are character numbers, below branches are character states, and the red numbers below the branches are bootstrap values in (a)

The analysis by PAUP produced two most parsimonious trees (Additional file 4: Figure S4), and the consensus tree is shown in Fig. 11b (tree length $=73$ steps, $\mathrm{CI}=0.5735, \mathrm{RI}=0.6630)$. Two characters are uninformative (characters 23 and 25), but we did not exclude them in our analyses because they provide additional information for individual tree branches. There are 24 parsimony-informative characters.

The monophyly of the Mesopsychidae is supported by three synapomorphic characters (Fig. 11a). They are: 1), the forewing Rs + MA vein forks from the R1 vein far distal to the MP vein that originates from $\mathrm{CuA}$ (Character 3:1); 2), the forewing $\mathrm{CuP}$ vein occurs almost at the same level or distal to mid-length of the wing (Character 14:1); and 3), the anal area is expanded on the forewing (Character 22:2). One of the basalmost taxa of the Mesopsychidae is Epicharmesopsyche, whose sister-group relationship with other species of the ingroups is supported by one synapomorphic character, namely that the antennae is short and filiform (Character 24:1). The basal position of Epicharmesopsyche is indirectly determined, as this genus possesses one described species and is monotypic.
The monophyly of Vitimopsyche is supported by two synapomorphic characters. The first feature is the forewing MP forking distal to the Rs + MA bifurcation (Character 10:2). The second character is the forewing crossvein mp2mp3 occurring considerably distal to the MP1 +2 bifurcation point (Character 20:2). The systematic position of the new species, Vitimopsyche pristina sp. nov., also is confirmed by the one synapomorphic character of the hind wing Sc vein of medium length that is present slightly proximal to the MA vein bifurcation (Character 23:1).

The monophyly of Lichnomesopsyche is supported by one unambiguous character: the forking of the MP and Rs + MA veins very close to or at the same level in the forewing (Character 10:1). In addition, there are two nonhomologous characters of: 1) a Rs + MA bifurcation from the R1 vein present slightly distal to where the MP vein originates from the $\mathrm{CuA}$ vein (Character 3:0); and 2) the forewing cup-cua crossvein is far distal to the MP vein and originates from the $\mathrm{CuA}$ vein (Character 13:0). These features render the three species of Lichnomesopsyche, including Lichnomesopsyche prochorista sp. nov., as forming one clade equivalent to a genus. 
Mesopsyche, in contrast, is a paraphyletic group, as the three species are scattered across the phylogenetic tree. The sister group of Mesopsyche triareolata is supported by two homologous characters: 1) absence of a crossvein between R1 and C (Character 6:0); and 2) the posterior margin of the forewings bearing an emargination at the $\mathrm{CuP}$ vein apex (Character 11:1). The basal position of Mesopsyche triareolata clade, however, is only indirectly determined. The clade of Mesopsyche shcherbakovi and its sister group is supported by one synapomorphic character, the MP1 + 2 forking is proximal to the MA forking in the forewing (Character 5:2). We suggest revising the taxonomy of these two species, pending future discovery and study of additional new specimens.

Mesopsyche dobrokhotovae exhibits close affinity to species of Permopsyche, particularly in that the base of the $\mathrm{CuA}$ vein is oblique to transverse and not inclined backwards [21]. Mesopsyche dobrokhotovae mainly conforms to the character of Permopsyche. The systematic position of Mesopsyche dobrokhotovae should be revised, a conclusion confirmed by one synapomorphic character, the forewing $\mathrm{Sc}$ fore-branch $\left(\mathrm{Sc}_{1}\right)$ vein ending at a point proximal to the $1 \mathrm{~A}$ vein terminus (Character 1:2). Consequently, we propose to transfer Mesopsyche dobrokhotovae to the genus Permopsyche, as Permopsyche dobrokhotovae (Novokshonov, 1997) comb. nov. Three species of Permopsyche and Mesopsyche dobrokhotovae are shown as a sister clade to Lichnomesopsyche. It is interesting to note the geochronologically wide age distinctions among these species, ranging from the Late Permian to Middle Jurassic.

The resulting consensus tree by PAUP (Fig. 11b) is very similar to the tree by NONA (Fig. 11a). Only two differences are present. One distinction is the relationship among the three outgroups. The results from NONA exhibits a closer relationship of Pseudopolycentropus janeannae and the ingroups, whereas the result by PAUP shows a parallel relationship of three outgroups and an ingroup. The other feature resolved by NONA is the interspecies relationship of the two genera, Lichnomesopsyche and Permopsyche, which was not resolved by PAUP.

Based on the two phylogenetic analyses, Mesopsychidae is a monophyletic group; in addition, two of its genera, Vitimopsyche and Lichnomesopsyche, also are monophyletic (Fig. 11). Permopsyche and Mesopsyche are paraphyletic. Epicharmesopsyche is a monotypic species. Although the relationships among the genera are incompletely resolved, we have carried out a geometric morphometric analyses to supplement the results of our phylogenetic analyses.

Results of geometric morphometric analysis of forewings For the first study, a forewing geometric analysis consisted of 13 ingroups, three outgroups, 38 landmarks, but no crossvein characters. An unweighted pair-group method that employs arithmetic averages (UPGMA) produced Tree 1 (Fig. 12a). The results of this study show the phenetic relationships without consideration of evolutionary relationships among the sixteen scorpionfly wing samples. A second study consisted of twelve ingroups and three outgroups, using 42 landmarks and two crossvein characters that produced Tree 2 (Fig. 12b).

From the resulting geometric morphometric Trees 1 and 2 (Fig. 12a, b), which are nearly congruent, we obtain the following five conclusions. First, Lichnomesopsyche prochorista sp. nov. has wing venation most similar to those of the other two species of the genus Lichnomesopsyche. Second, Vitimopsyche pristina sp. nov. has wing venation most similar to those of the two other species of the genus Vitimopsyche. Third, the group containing three species of Permopsyche and $M$. dobrokhotovae has very similar wing venation, which is different from that of the genus Lichnomesopsyche and other taxa in Mesopsychidae. Fourth, the venation of $M$. triareolata and $M$. shcherbakovi are unique and distinct from other taxa or groups of Mesopsychidae. Fifth, Epicharmesopsyche pentavenulosa is a unique taxon with venation different from all other ingroups of Mesopsychidae, shown in Tree 1 (Fig. 12a).

The result of the geometric morphometric analyses also indicates that Mesopsyche is not monophyletic, and that Mesopsyche dobrokhotovae has an affinity with species of Permopsyche. This is consistent with the results of our phylogenetic analyses and with comparisons of the original description, line drawings, and photographs. As a result, we further validate our proposal for transferal of Mesopsyche dobrokhotovae to Permopsyche dobrokhotovae (Novokshonov, 1997) comb. nov. [18], and consider that the taxonomic positions of the other two species should be revised, pending availability of new specimens and additional study. Based on current information, it is hypothesized that the geochronologic longevity and geographic distribution of Permopsyche extended from the Upper Permian of Russia and Australia to the Upper Triassic of the Ukraine [14].

\section{Discussion}

\section{Taxonomy and phylogeny of mesopsychidae}

Although most of the examined specimens have preserved wings rich in structural characters, due to limited number of fossil specimens described, this study is the first attempt to compile data and conduct phylogenetic and geometric morphometric analyses based on previously described and new species. These phylogenetic results support the hypothesis that Mesopsychidae is a monophyletic group. The systematic positions of the two newly described species, $L$. prochorista sp. nov. and $V$. pristina sp. nov. are validated. Vitimopsyche pristina sp. 


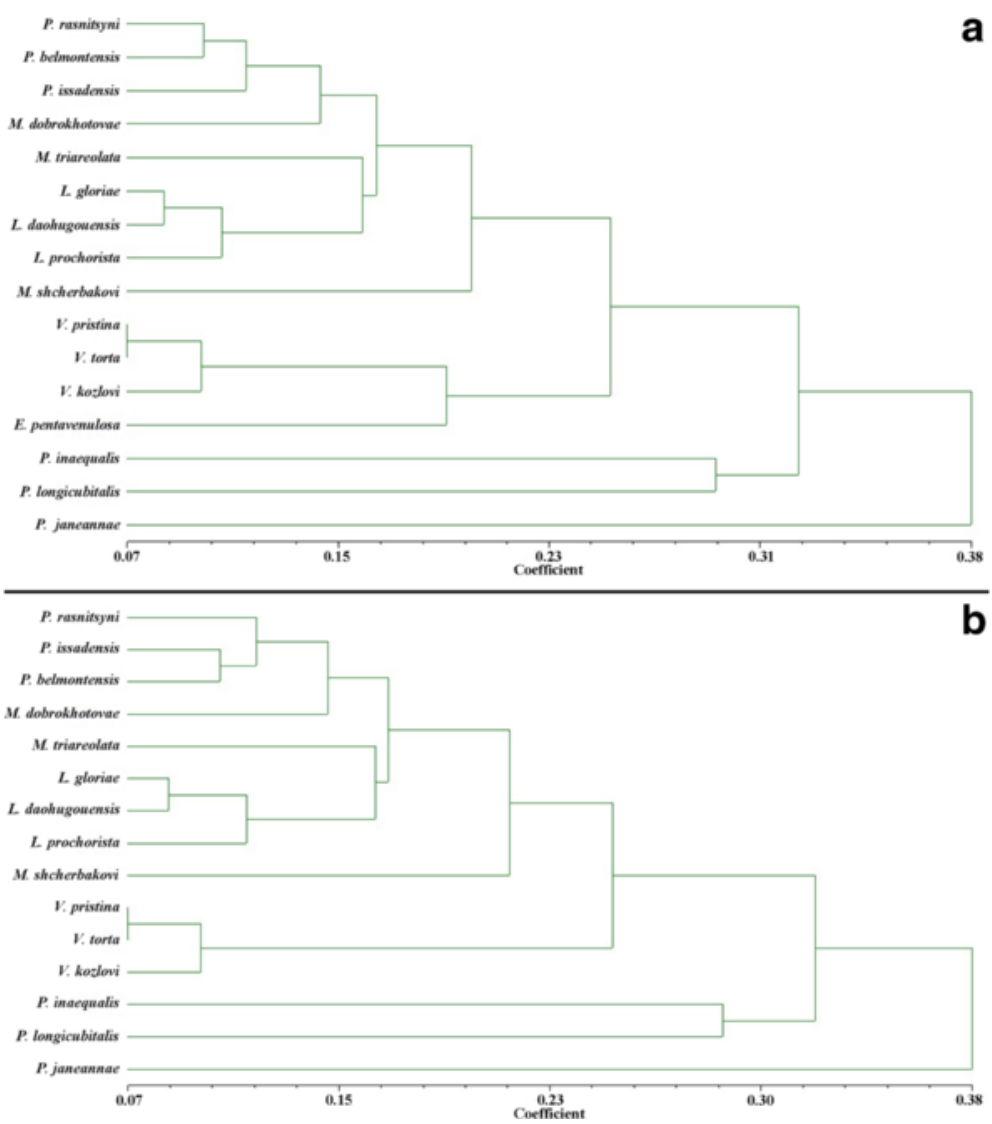

Fig. 12 Resulting Trees for the geometric morphometric analyses. a Tree 1 for 38 landmarks (including 3 outgroups, no crossvein characters). b Tree 2 for 42 landmarks (including 3 outgroups, two crossvein characters)

nov. represents the earliest fossil record of the genus Vitimopsyche, thus, extending the genus from the Lower Cretaceous to the latest Middle Jurassic. Based on our phylogenetic and geometric morphometric analyses, we propose erection of the taxon Permopsyche dobrokhotovae (Novokshonov, 1997) comb. nov., and suggest a taxonomic revision of the two other species of Mesopsyche in the future.

\section{Comparison of phylogenetic and geometric morphometric analyses}

For a better perspective regarding relationships among representative genera and species of Mesopsychidae, we applied two methods for analyses of the same specimens. Both approaches were useful for understanding the intergeneric relationships among taxa and to infer the systematic positions of the two new species. In the phylogenetic analysis, many morphological characteristics were chosen, including abundant characters of the forewing, and a few characters of the hind wing and body. By comparison, the geometric morphometric analyses only employed forewing landmarks. The character states of phylogenetic analyses are discrete states, but landmark analysis used in geometric morphometric analyses allow for continuous changes of a particular landmark character. Because many landmarks occur on the wing margin, the geometric morphometric analyses include comparisons of wing shapes [28], which is not part of the phylogenetic analysis. Alternatively, character states of phylogenetic analyses allow some missing character data, which frequently occur for fossil specimens. The geometric morphometric analyses do not allow for missing landmarks, unless they are added by invoking assumptions. Consequently, both methodologies, based on the same set of specimens, complement each other to provide a better understanding of the phylogenetic and phenetic relationships among these specimens.

The resulting trees from the two methods exhibit a fundamental consistency and similarity, but, with two obvious differences as shown in Additional file 5: Figure S5: The first distinction is the varying placement of Mesopsyche triareolata. In the tree shown in Additional file 5: Figure S5B, Mesopsyche triareolata and the species of Lichnomesopsyche are in one clade, whereas in the phylogenetic tree in Additional file 5: Figure S5A, $M$. triareolata and the rest of ingroup species are sister 
groups. The second distinction is that the sister groups of Epicharmesopsyche pentavenulosa are different. As mentioned previously, the most basal position of Mesopsyche triareolata is indirectly supported by its sister group, which are represented by five landmarks: 2 vs. 35 and 37, 38 vs. 19. Since geometric morphometric analyses treat all landmarks equally and without weighting, the positions of other landmarks, such as 33 landmarks for Tree 1 (Fig. 12a) and 37 for Tree 2 (Fig. 12b), seem to have more of a significant impact on relative venational similarity and the phenetic placement of $M$. triareolata in Trees 1 and 2.

\section{Origin and early evolution of the mesopsychid siphonate proboscis}

The phylogenetic analysis of Mesopsychidae sheds light on the origin of the siphonate proboscis and in its closest related family, the Pseudopolycentropodidae. The second most basal Mesopsychidae, Epicharmesopsyche pentavenulosa, apparently lacked a proboscis [23], although the mouthpart condition of the two outgroups, Permopanorpa inaequalis, Protopanorpa longicubitalis and Mesopsyche triareolata, the most basal mesopsychid, remain unknown. Additionally, the proboscis of Pseudopolycentropodidae is structurally very different from that of the Mesopsychidae [8, 12]. Consequently, it appears that the proboscis was evolved independently in the Pseudopolycentropodidae, also in the Vitimopsyche and possibly in the Lichnomesopsyche clades of the Mesopsychidae. Nevertheless, the mouthpart conditions of the intervening Mesopsyche shcherbakovi and the species of Permopsyche, the sister clade to Lichnomesopsyche, remain unknown. More broadly, within late Paleozoic to mid Mesozoic Mecoptera, the Nedubroviidae [9] and Aneuretopsychidae [3, 10] also have long-proboscid, siphonate mouthparts. This suggests that the longproboscid condition might independently have originated four or possibly five (assuming independent originations in Vitimopsyche and Lichnomesopsyche) times within early Mecoptera.

The pattern of the origin of the siphonate proboscis four or five times in Mecoptera contrasts dramatically with that of Lepidoptera in which evidence indicates a single origination event for a considerably more diverse clade [51]. Another significant difference is that the lepidopteran proboscis is derived from paired maxillary galeae [52], whereas the mecopteran proboscis consists of paired labial elements. Unlike lepidopterans, the construction of the mecopteran's labially derived proboscis is based on elongation of paired labial elements such as glossae or palps that are conjoined to anatomically form the siphon for the imbibition of fluids [3]. The origin of the mecopteran proboscis likely has an evolutionary developmental explanation. Smith and Jockusch [53] recently have documented such a transformation in embryonic mouthpart development in the beetle, Tribolium castaneum, which has well developed, chewing, mandibulate mouthparts. In $T$. castaneum the specificity functions of the genes extradenticle (ext) and homothorax ( $h$ th) were subject to gene knockdown, providing interference RNA (RNAi) phenotypes. The resulting adult mouthpart malformations of this mandibulate insect included modifications of the maxillary and labial regions. The maxillary region displayed enlargement of some elements, transformation of proximal structures to more distal identity, and inter-element fusions, though not formation of the anatomical precursor to siphonate mouthparts.

By contrast, the adult labium in $T$. castaneum underwent a major structural transformation that could represent the initial stages of a siphonate proboscis (Fig. 13). Upon knockdown of the ext and hth genes by RNAi treatment, there was: 1) a change of more proximal element regions to a more distal identity, 2) a narrowing of the prementum and mentum basal regions; 3) elongation of the palpiger sclerite that bears the labial palps, and most significantly, 4) deletion of the ligula and most of the prementum occurring between the labial palps, and 5) reduction and medial fusion of the labial palps into a single, somewhat prolonged structure [53]. Other knockdown genes, such as proboscipedia $(p b)$, instead resulted in transformation of the labial palpi into a leglike structures, indicating that it is the ext and hth genes in T. castaneum that largely is responsible for alteration of nominal mandibulate mouthparts into an incipiently siphonate condition. It is unclear if the medially conjoined labial structure was tubular in nature, or if it had any connection to an anatomical mouth. Repeated rounds of suppression of ext and hth genes could explain initial stages of the proboscis origin among early Mecoptera.

\section{Conclusions}

Phylogenetic results support that Mesopsychidae is a monophyletic group. The systematic positions of L. prochorista sp. nov. and $V$. pristina sp. nov. are confirmed as belonging, respectively, to the Lichnomesopsyche and Vitimopsyche lineages. The existence of Vitimopsyche pristina sp. nov. extends this genus from the Lower Cretaceous to the latest Middle Jurassic. Based on our phylogenetic analyses and geometric morphometric analyses, we propose to transfer Mesopsyche dobrokhotovae to Permopsyche, and suggest revising the taxonomy of the other two species, pending the discovery and study of new specimens. In addition, tree topology supports the origin of the siphonate proboscis in the common ancestor to the Vitimopsyche and Lichnomesopsyche clades, possibly in an independent fashion, 


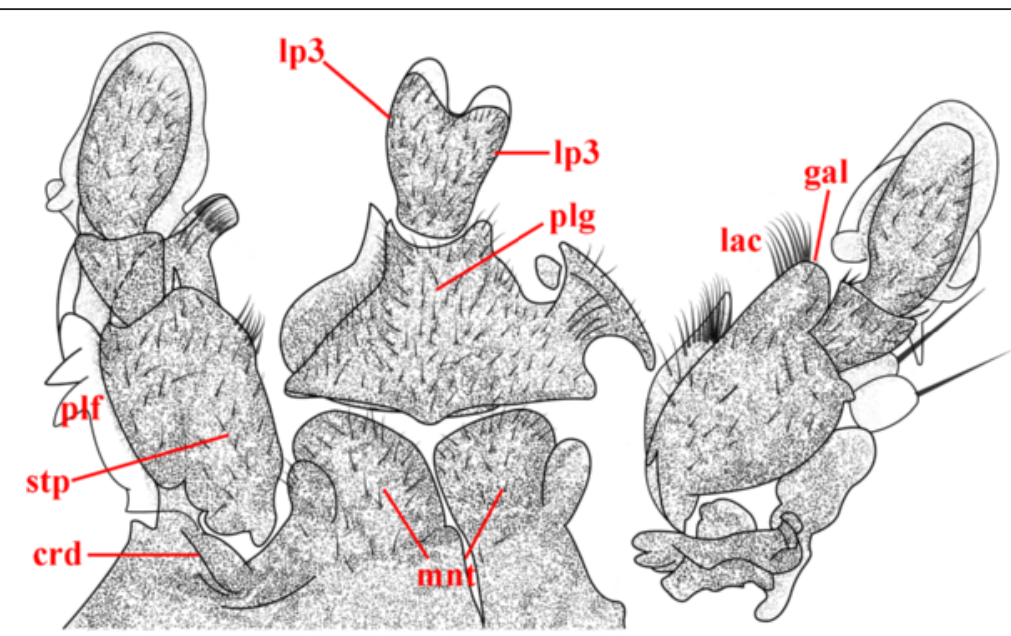

Fig. 13 An adult mouthpart phenotype with medial fusion of labial palps in Tribolium castaneum resulting from larval RNAi knockdown of the genes homothorax (hth) and extradenticle (ext). The example represents a more severe case in the transformation of the loss of labial glossa and paraglossal elements, significant size reduction of the mentum (mnt) and prementum, and fusion of the labial palps into a single medial structure. Abbreviations for maxillary elements are: crd, cardo; stp, stipes; plf, palpiger; lac, lacinia; and gal, galea. Abbreviations for labium are: plg, paliger, Ip3 labial palp segment 3. This figure was redrawn from Fig. 1P of Smith and Jockusch (2014) [53]

and siphon loss in Epicharmesopsyche. It is suggested that the long-proboscid condition may have independently originated up to five times within early Mecoptera, namely Nedubroviidae, Aneuretopsychidae, Pseudopolycentropodidae and Mesopsychidae, with possible separate originations in Vitimopsyche and Lichnomesopsyche. It is hypothesized that repeated rounds of suppression of ext and $h t h$ genes could explain initial stages of the proboscis origin among early Mecoptera. Future phylogenetic and geometric morphometric studies, and new mouthpart examinations of additional fossil specimens and better preserved material will augment understanding of the origin, evolution and phylogeny of Mesopsychidae and their siphonate proboscides.

\section{Additional files}

Additional file 1: Figure S1. The selection of the morphological characters in forewing. (A) Lichnomesopsyche daohugouensis, from Ren, Labandeira, and Shih, 2010 [21], represent the ingroup species. (B) Protopanorpa longicubitalis, from Bashkuev, 2010 [39]. (C)

Pseudopolycentropus janeannae, from Ren et al., 2010 [8]. The veins in brown denote the character 2 , in green denote the character 6 , and in purple denote the character 7 . The red numbers denote the number of branches for characters 8 and 9 , the blue numbers show the positions and number-counting of crossveins for character 21. Green lines denote the middle of the wings, character 14 . The areas shown in blue denote the anal area in the forewing, character 22. Green circles show the spots, character 16. Blue angles denote the inclination of the cup-cua, character 12. Red dots denote other forewing characters representing the relative positions of the bifurcating points and intersections of veins and wing margin. (TIF $1300 \mathrm{~kb}$ )

Additional file 2: Figure S2. Lichnomesopsyche daohugouensis Ren, Labandeira and Shih, 2010, new specimen CNU-MEC-NN-2015007p/c. (A) Photograph of part. (B) Photograph of counterpart. (C) Overlay drawing of part. (D) Line drawings of hind wings. Scale bars represent $5 \mathrm{~mm}$ in (A)-(D). (TIF $5102 \mathrm{~kb}$ )
Additional file 3: Figure S3. Photographs of Lichnomesopsyche daohugouensis Ren, Labandeira and Shih, 2010, new specimens CNUMEC-NN-2015013 and CNU-MEC-NN-2015014. (A) Specimen CNU-MECNN-2015014. (B) Specimen CNU-MEC-NN-2015013. (C) Female genitalia of specimen CNU-MEC-NN-2015014 under ethanol. (D) Head and part of the forelegs of specimen CNU-MEC-NN-2015014 under ethanol. Scale bars represent $5 \mathrm{~mm}$ in (A) and (B), $2 \mathrm{~mm}$ in (C) and (D). (TIF $6972 \mathrm{~kb}$ )

Additional file 4: Figure S4. Results of phylogenetic analysis by PAUP. (A) The most parsimonious tree 1. (B) The most parsimonious tree 2. (TIF $295 \mathrm{~kb}$ )

Additional file 5: Figure S5. Comparison of the most parsimonious tree and the Tree 1 of geometric morphometric analyses. (A) The most parsimonious tree (without showing the characters and their states, by NONA). (B) Tree 1 of geometric morphometric analyses (Tree 1 flipped to make it easier to compare with the phylogenetic tree, and without showing the tree length). The red rectangles denote the different positions of Mesopsyche triareolata. The green rectangles denote the different positons of Epicharmesopsyche pentavenulosa. (TIF $477 \mathrm{~kb}$ )

\section{Competing interests}

The authors declare that there are non-financial competing interests (political, personal, religious, ideological, academic, intellectual, commercial or any other), nor are there competing interests in the manuscript.

\section{Authors' contributions}

Conceived and designed the experiments: XDL MJS DR. Performed the analyses and experiments: XDL MJS DR. Analyzed the data: XDL MJS CCL DR. Contributed materials/analysis tools: XDL MJS DR. Wrote the manuscript: XDL MJS CCL DR. Photographs: XDL. Line drawings: XDL MJS. Evolutionary developmental input: CCL. All authors read and approved the final manuscript.

\section{Authors' information}

$X D L$ is a graduate student in the Key Lab of Insect Evolution and Environmental Changes at Capital Normal University, Beijing, China. MJS is a student at the Union County Magnet High School, Scotch Plains, New Jersey, USA. DR is a Professor at the Key Lab of Insect Evolution and Environmental Changes at Capital Normal University, Beijing, China. CCL is an Adjunct Professor at Department of Entomology and BEES Program, University of Maryland, College Park, Maryland, USA and a Senior Research Scientist and Curator of Fossil Arthropods in the Department of Paleobiology, National Museum of Natural History, Smithsonian Institution, Washington DC, USA. 


\section{Acknowledgements}

We thank Dr. Yongjie Wang for his help and guidance for our use of the phylogenetic and geometric morphometric software. We thank Drs. Taiping Gao, Weiting Zhang, Qiang Yang and Chaofan Shi for their assistance in improving the manuscript. We appreciate Longfeng Li, Sulin Liu, Xiao Zhang, Yizi Cao and Chen Wang of Capital Normal University for their valuable comments and fruitful suggestions. This research is supported by the National Basic Research Program of China (973 Program) (2012CB821906), the National Natural Science Foundation of China (No. 31230065, 41272006), Great Wall Scholar and KEY project of the Beijing Municipal Commission of Education (KZ201310028033), Program for Changjiang Scholars and Innovative Research Team in University (IRT13081). This is contribution 313 of the Evolution of Terrestrial Ecosystems consortium at the National Museum of Natural History, in Washington, D.C.

\section{Author details}

${ }^{1}$ College of Life Sciences, Capital Normal University, Beijing, China. ${ }^{2}$ Union County Magnet High School, Scotch Plains, NJ 07076, USA. ${ }^{3}$ Department of Paleobiology, National Museum of Natural History, Smithsonian Institution, Washington, DC 20013, USA. ${ }^{4}$ Department of Entomology and BEES Program, University of Maryland, College Park, MD 20742, USA.

\section{Received: 27 November 2015 Accepted: 19 December 2015} Published online: 04 January 2016

\section{References}

1. Proctor M, Yeo P, Lack A. The natural history of pollination. Portland: Timber Press; 1996.

2. Ollerton J, Coulthard E. Evolution of animal pollination. Science. 2009;326: 808-9.

3. Ren D, Labandeira CC, Santiago-Blay JA, Rasnitsyn AP, Shih CK, Bashkuev AS, et al. A probable pollination mode before angiosperms: Eurasian, long-proboscid scorpionflies. Science. 2009;326:840-7.

4. Peñalver E, Arillo A, la Pérez-de Fuente FR, Riccio ML, Delclòs X, Barrón E, et al. Long-proboscid flies as pollinators of Cretaceous gymnosperms. Curr Biol. 2015;25(14):1917-23. doi:10.1016/j.cub.2015.05.062.

5. Krzemiński W, Soszyńska MA. A new genus and species of scorpionfly (Mecoptera) from Baltic amber, with an unusually developed postnatal organ. Syst Entomol. 2012;37:223-8.

6. Zhang JX, Shih CK, Petrulevičius JF, Ren D. A new fossil eomeropid (Insecta, Mecoptera) from the Jiulongshan Formation, Inner Mongolia, China. Zoosystema. 2011;33:443-50.

7. Ren D, Shih CK, Labandeira CC. A well-preserved aneuretopsychid from the Jehol Biota of China (Insecta, Mecoptera, Aneuretopsychidae). ZooKeys. 2011;129:17-28.

8. Ren D, Shih CK, Labandeira CC. New Jurassic pseudopolycentropodids from China (Insecta: Mecoptera). Acta Geol Sin-Engl. 2010;84:22-30.

9. Bashkuev AS. Nedubroviidae, a new family of Mecoptera: the first Paleozoic long-proboscid scorpionflies. Zootaxa. 2011;2895:47-57.

10. Rasnitsyn AP, Kozlov MV. A new group of fossil insects: scorpions with cicad and butterfly adaptations. Trans USSR Acad Sci, Earth Sci Sect. 1991;310:233-6.

11. Labandeira CC, Kvaček J, Mostovski MB. Pollination drops, pollen, and insect pollination of Mesozoic gymnosperms. Taxon. 2007;56:663-95.

12. Labandeira CC. The pollination of mid Mesozoic seed plants and the early history of long-proboscid insects. Ann Mo Bot Gard. 2010;97:469-513.

13. Grimaldi DA, Engel MS. Evolution of the Insects. New York: Cambridge University Press; 2005. p. 469.

14. Tillyard RJ. Mesozoic insects of Queensland. No. 1. Planipennia, Trichoptera, and the new order Protomecoptera. P Linn Soc N S W. 1917;42:175-200.

15. Tillyard RJ. Mesozoic insects of Queensland. No. 3. Odonata and Protodonata. P Linn Soc N S W. 1918;43:417-36.

16. Riek EF. Fossil mecopteroid insects from the upper Permian of New South Wales. Rec Austral Mus. 1953;23(2):55-87.

17. Riek EF. A new collection of insects from the Upper Triassic of South Africa. Ann Natal Mus. 1976;22:791-820.

18. Novokshonov VG. Some Mesozoic scorpionflies (Insecta: Panorpida= Mecoptera) of the families Mesopsychidae, Pseudopolycentropodidae, Bittacidae, and Permochoristidae. J Paleontol. 1997;31:65-71.

19. Novokshonov VG, Sukacheva ID. Fossil scorpionflies of the "Suborder" Paratrichoptera (Insecta: Mecoptera). J Paleontol. 2001;35(2):173-82.
20. Hong YC. Midtriassic new genera and species of Mesopanorpodidae (Insecta, Mecoptera) from Shaanxi. China Acta Zootaxa Sin. 2007;32(2):261-7.

21. Ren D, Labandeira CC, Shih CK. New Mesozoic Mesopsychidae (Mecoptera) from northeastern China. Acta Geol Sin-Engl. 2010;84(4):720-31.

22. Bashkuev AS. The earliest Mesopsychidae and revision of the family Mesopanorpodidae (Mecoptera). ZooKeys. 2011;130:263-79.

23. Shih CK, Qiao X, Labandeira CC, Ren D. A new mesopsychid (Mecoptera) from the Middle Jurassic of Northeastern China. Acta Geol Sin-Engl. 2013; 87(5):1235-41.

24. Lambkin KJ. The Mesopsychidae (Mecoptera) of the Queensland Triassic. Austral Ent. 2014;41(3):135-46.

25. Swisher CC, Wang YQ, Wang XL, Xu X, Wang Y. Cretaceous age for the feathered dinosaurs of Liaoning, China. Nature. 1999;400:58-61.

26. Ren D, Shih CK, Gao TP, Yao YZ, Zhao YY. Silent Stories-Insect Fossil Treasures from Dinosaur Era of the Northeastern China. Beijing: Science Press; 2010. 322 p.

27. Ren D, Lu LW, Guo ZG, Ji SA. Faunae and Stratigraphy of Jurassic-Cretaceous in Beijing and the Adjacent Areas. Beijing: Seismic Publishing House; 1995. 222 p.

28. Wang YJ, Labandeira CC, Shih CK, Ding QL, Wang C, Zhao YY, et al. Jurassic mimicry between a hangingfly and a ginkgo from China. Proc Natl Acad Sci U S A. 2012;109(50):20514-9.

29. Pretorius E, Scholtz CH. Geometric morphometries and the analysis of higher taxa: A case study based on the metendosternite of the Scarabaeoidea (Coleoptera). Biol J Linn Soc Lond. 2001;74:35-50.

30. Bai $M$, Jarvis K, Wang SY, Song KQ, Wang YP, Wang ZL, et al. A second new species of ice crawlers from China (Insecta: Grylloblattodea), with thorax evolution and the prediction of potential distribution. PLoS One. 2010;5(9): e12850.

31. Bai M, Ahrens D, Yang XK, Ren D. New fossil evidence of the early diversification of scarabs: Alloioscarabaeus cheni (Coleoptera: Scarabaeoidea) from the Middle Jurassic of Inner Mongolia, China. Insect Sci. 2012;19:159-71.

32. Bai M, Beutel RG, Shih CK, Ren D, Yang XK. Septiventeridae, a new and ancestral fossil family of Scarabaeoidea (Insecta: Coleoptera) from the Late Jurassic to Early Cretaceous Yixian Formation. J Syst Palaeont. 2013;11(3):359-74.

33. De Meulemeester T, Michez D, Aytekin AM, Danforth BN. Taxonomic affinity of halictid bee fossils (Hymenoptera: Anthophila) based on geometric morphometrics analyses of wing shape. J Syst Palaeontol. 2012;10(4):755-64.

34. Perrard A, Villemant C, Carpenter JM, Baylac M. Differences in caste dimorphism among three hornet species (Hymenoptera: Vespidae): forewing size, shape and allometry. J Evol Biol. 2012;25:1389-98.

35. Roggero A, Passerin D, Entrèves P. Geometric morphometric analysis of wing variation between two populations of the Scythris obscurella speciesgroup: geographic or interspecific differences? (Lepidoptera: Scythrididae). Revta Lepidopt. 2005;33(130):101-12.

36. Novokshonov VG. Order Panorpida Latrielle, 1802. In: Rasnitsyn AP, Quicke DLJ, editors. History of insects. Dordrecht: Kluwer Academic Press; 2002. p. 194-9.

37. Tillyard RJ. Kansas Permian insects. Part 7. The Order Mecoptera. Am J Sci (Ser 5). 1926;11(62):133-64.

38. Beckemeyer RJ, Hall JD. Permopanorpa inaequalis Tillyard, 1926 (Insecta: Holometabola: Panorpida: Permopanorpidae): A fossil mecopteroid newly reported for the Lower Permian Wellington Formation of Noble County. Oklahoma Trans Kans Acad Sci. 2007;110(1/2):23-9.

39. Bashkuev AS. New scorpionflies (Insecta: Mecoptera: Permochoristidae) from the Ufimian of Cisuralia. J Paleontol. 2010;44(3):291-6.

40. Nixon KC. WinClada, Version 1.00.08. Program and Documentation. Ithaca (NY): Cornell University Press; 2002.

41. Goloboff PA. NoName (NONA), Version 2.0. Program and Documentation. Tucumán: Fundación Instituto Miguel Lillo; 1997.

42. Swofford DL. PAUP: Phylogenetic Analysis Using Parsimony (and Other Methods), Version 4.0b10. Sunderland (MA): Sinauer Associates; 2003.

43. Rohlf FJ. tps-UTIL, File utility Program. Version 1.38 (software and manual). Stony Brook: Department of Ecology and Evolution, State University of New York at Stony Brook; 2006.

44. Rohlf FJ. tps-D/G, File Utility Program. Version 1.38 (software and manual). Stony Brook: Department of Ecology and Evolution, State University of New York at Stony Brook; 2006.

45. Rohlf FJ. tps-SUPER. Version 1.14. (software and manual). Stony Brook: Department of Ecology and Evolution, State University of New York at Stony Brook; 2004 
46. Rohlf FJ. tps-SPLIN. Thin-Plate Spline. Version 1.20 (software and manual). Stony Brook: Department of Ecology and Evolution, State University of New York at Stony Brook; 2004.

47. Bookstein FL. Morphometric Tools for Landmark Data: Geometry and Biology. Cambridge: Cambridge University Press; 1991.

48. Rohlf FJ. NTSYS-pc: Numerical Taxonomy and Multivariate Analysis System, Version 2.20 for Windows (software and manual). New York: Exeter Software; 2007.

49. He HY, Wang $X L$, Zhou ZH, Zhu RX, Jin F, Wang F, et al. ${ }^{40} \mathrm{Ar} /{ }^{39} \mathrm{Ar}$ dating of ignimbrite from Inner Mongolia, northeastern China indicates a post-middle Jurassic age for the Daohugou Bed. Geophys Res Lett. 2004;31:206-9.

50. Walker JD, Geissman JW, Bowring SA, Babcock LE. The Geological Society of America geologic time scale. Geol Soc Am Bull. 2013;125:269-72.

51. Krenn H. Feeding mechanisms of adult Lepidoptera: Structure, function, and evolution of the mouthparts. Annu Rev Entomol. 2010;55:307-27.

52. Krenn $\mathrm{H}$, Kristensen NP. Evolution of proboscis musculature in Lepidoptera. Eur J Entomol. 2004;101:565-75.

53. Smith FW, Jockusch EL. Hox genes require homothorax and extradenticle for body wall identity specification but not for appendage identity specification during metamorphosis of Tribolium castaneum. Dev Biol. 2014;395:182-97.

54. Zalessky G. Sur deux restes d'insectes fossils provenant du basin de Kousnetzk et sur l'age geologique des depots qui les renferment. Bull Soc Gèol France. 1935;5(5):687-95.

55. Martynov AV. Liassic insects from Shurab and Kyzyl-Kiya. Tr Paleontol Inst Akad Nauk. 1937;7:1-231.

\section{Submit your next manuscript to BioMed Central and we will help you at every step:}

- We accept pre-submission inquiries

- Our selector tool helps you to find the most relevant journal

- We provide round the clock customer support

- Convenient online submission

- Thorough peer review

- Inclusion in PubMed and all major indexing services

- Maximum visibility for your research

Submit your manuscript at www.biomedcentral.com/submit 